\title{
Taming the wild: resolving the gene pools of non-model Arabidopsis lineages
}

\author{
Nora Hohmann ${ }^{1}$, Roswitha Schmickl ${ }^{1,2}$, Tzen-Yuh Chiang ${ }^{3}$, Magdalena Lučanová ${ }^{2,4}$, Filip Kolár ${ }^{2,4}$,
} Karol Marhold ${ }^{2,5}$ and Marcus A Koch ${ }^{1 *}$

\begin{abstract}
Background: Wild relatives in the genus Arabidopsis are recognized as useful model systems to study traits and evolutionary processes in outcrossing species, which are often difficult or even impossible to investigate in the selfing and annual Arabidopsis thaliana. However, Arabidopsis as a genus is littered with sub-species and ecotypes which make realizing the potential of these non-model Arabidopsis lineages problematic. There are relatively few evolutionary studies which comprehensively characterize the gene pools across all of the Arabidopsis supra-groups and hypothesized evolutionary lineages and none include sampling at a world-wide scale. Here we explore the gene pools of these various taxa using various molecular markers and cytological analyses.
\end{abstract}

Results: Based on ITS, microsatellite, chloroplast and nuclear DNA content data we demonstrate the presence of three major evolutionary groups broadly characterized as A. lyrata group, A. halleri group and A. arenosa group. All are composed of further species and sub-species forming larger aggregates. Depending on the resolution of the marker, a few closely related taxa such as A. pedemontana, A. cebennensis and A. croatica are also clearly distinct evolutionary lineages. ITS sequences and a population-based screen based on microsatellites were highly concordant. The major gene pools identified by ITS sequences were also significantly differentiated by their homoploid nuclear DNA content estimated by flow cytometry. The chloroplast genome provided less resolution than the nuclear data, and it remains unclear whether the extensive haplotype sharing apparent between taxa results from gene flow or incomplete lineage sorting in this relatively young group of species with Pleistocene origins.

Conclusions: Our study provides a comprehensive overview of the genetic variation within and among the various taxa of the genus Arabidopsis. The resolved gene pools and evolutionary lineages will set the framework for future comparative studies on genetic diversity. Extensive population-based phylogeographic studies will also be required, however, in particular for A. arenosa and their affiliated taxa and cytotypes.

Keywords: Chloroplast, Cytology, Evolution, ITS, Microsatellites, Systematics, Taxonomy

\section{Background}

\section{Arabidopsis: life in the fast lane}

Less than a decade ago "Arabidopsis and its poorly known relatives" was the title chosen to introduce the closest relatives of Arabidopsis thaliana to a broader readership [1]. This review summarized both the systematics and taxonomy of the genus and also the ecologically important traits to be studied in A. thaliana's "wild" relatives. Its necessity was obvious because until 1999, a huge number of species (60) were recognized in Arabidopsis in

\footnotetext{
* Correspondence: marcus.koch@cos.uni-heidelberg.de

${ }^{1}$ Centre for Organismal Studies (COS) Heidelberg, Heidelberg University, Heidelberg 69120, Germany

Full list of author information is available at the end of the article
}

the traditional sense. Arabidopsis' taxonomical history was compiled in detail more than 10 years ago [2,3], and nine Arabidopsis species with several subspecies were recognized by this time. Based on this work and unraveling the evolutionary history of the genus Arabis [4-7], which differs morphologically from Arabidopsis only in the position of the cotyledons relative to the radicle in the seeds, a new systematic concept was presented 10-15 years ago $[4,8,9]$. Several species and subspecies have since been added either because molecular studies provided new resolution [10] or because description of new species [11] led to changes in their respective taxonomic rank (species, subspecies, variety) [11-17].

\section{() Biomed Central}

(c) 2014 Hohmann et al.; licensee BioMed Central Ltd. This is an Open Access article distributed under the terms of the Creative Commons Attribution License (http://creativecommons.org/licenses/by/4.0), which permits unrestricted use, distribution, and reproduction in any medium, provided the original work is properly credited. The Creative Commons Public Domain Dedication waiver (http://creativecommons.org/publicdomain/zero/1.0/) applies to the data made available in this article, unless otherwise stated. 
Arabidopsis has been estimated to comprise of at least nine species and six subspecies [8], or up to 13 (or even more) species and nine subspecies [18] depending on the taxonomic approach and the identifier. The most recent studies, e.g. on A. arenosa and its segregates [19], and taxonomic entities within the genus Arabidopsis are summarized in Table 1 . Note that few of them will probably not be considered in future either because of insufficient diagnostic morphological characters or because they do not represent monophyletic lineages.

Table 1 Arabidopsis species diversity and taxonomy

\begin{tabular}{|c|c|c|}
\hline \multicolumn{3}{|l|}{ Arabidopsis arenosa species aggregate } \\
\hline \multicolumn{3}{|l|}{ Arabidopsis arenosa (L.) Lawalrée } \\
\hline subsp. arenosa & $(2 n=32)$ & Central and Western Europe, Scandinavia (lower altitudes) \\
\hline subsp. arenosa var. intermedia (Kovats) Hayek & $(2 n=32)$ & Southeastern Austrian Alps (similar to A. neglecta) \\
\hline subsp. borbasii (Zapałowicz) O’Kane \& Al-Shehbaz & $(2 n=32)$ & Central and Western Europe (mountain ranges, higher altitudes) \\
\hline Arabidopsis arenosa, unclear taxonomic treatment & $(2 n=16)$ & Balkans \\
\hline Arabidopsis carpatica, nom. prov. & $(2 n=16)$ & Carpathians (middle altitudes, calcareous bedrocks) \\
\hline \multicolumn{3}{|l|}{ Arabidopsis neglecta (Schultes) O'Kane \& Al-Shehbaz } \\
\hline subsp. neglecta & $(2 n=16)$ & Carpathians (alpine ranges) \\
\hline subsp. robusta, nom. prov. & $(2 n=32)$ & Carpathians (alpine ranges, only occasionally in lower altitudes) \\
\hline Arabidopsis nitida, nom. prov. & $(2 n=16)$ & Carpathians (mountain ranges, middle to subalpine altitudes) \\
\hline \multicolumn{3}{|l|}{ Arabidopsis petrogena (A. Kern) V.I. Dorof. } \\
\hline subsp. petrogena & $(2 n=16)$ & Carpathians, Pannonian lowland (maybe two varieties) \\
\hline subsp. exoleta, nom. prov. & $(2 n=32)$ & Carpathians (lower altitudes) \\
\hline \multicolumn{3}{|l|}{ Arabidopsis lyrata lineage } \\
\hline Arabidopsis lyrata subsp. lyrata (L.) O'Kane \& Al-Shehbaz & $(2 n=16)$ & Alaska, Canada, United States \\
\hline Arabidopsis lyrata subsp. petraea (L.) O'Kane \& Al-Shehbaz & $(2 n=16 / 32)$ & Europe \\
\hline \multicolumn{3}{|l|}{$=$ A. petraea (L.) V.I. Dorof. } \\
\hline $\begin{array}{l}\text { Arabidopsis petraea subsp. umbrosa (Turcz. Ex Steud.) } \\
\text { Elven \& D.F. Murray }\end{array}$ & $(2 n=16)$ & Arctic NE Asia, Siberia, Alaska, Canada \\
\hline $\begin{array}{l}\text { Arabidopsis petraea subsp. septentrionalis (N. Busch) } \\
\text { Elven \& D.F. Murray }\end{array}$ & $(2 n=32)$ & Arctic NE Europe, European Russia to Siberia \\
\hline Arabidopsis arenicola (Richardson ex Hook.) Al-Shehbaz et al. & $(2 n=16)$ & Arctic Canada and Greenland \\
\hline \multicolumn{3}{|l|}{ Arabidopsis halleri lineage } \\
\hline Arabidopsis halleri subsp. halleri (L.) O'Kane \& Al-Shehbaz & $(2 n=16)$ & Europe \\
\hline Arabidopsis halleri subsp. dacica (Heuff.) Kolník & $(2 n=16)$ & Carpathians, Romania \\
\hline Arabidopsis halleri subsp. gemmifera (Matsum.) O'Kane \& Al-Shehbaz & $(2 n=16)$ & Russia Far East, NE China, Korea, Japan, and Taiwan \\
\hline Arabidopsis halleri subsp. ovirensis (Wulfen) A. P. Iljinsk. & $(2 n=16)$ & $\begin{array}{l}\text { Austria only (all accessions from the Balkans belong } \\
\text { to subsp. halleri) }\end{array}$ \\
\hline Arabidopsis halleri subsp. tatrica (Pawł.) Kolník & $(2 n=16)$ & Tatra mountains, Slovakia \\
\hline Arabidopsis umezawana Kadota & $(2 n=?)$ & Japan, Hokkaido (alpine zone of Mt. Rishirizin), annual to biennial \\
\hline \multicolumn{3}{|l|}{ Other diploid taxa } \\
\hline Arabidopsis pedemontana (Boiss.) O’Kane \& Al-Shehbaz & $(2 n=16)$ & NW Italy \\
\hline Arabidopsis cebennensis (DC.) O'Kane \& Al-Shehbaz & $(2 n=16)$ & SE France, Massif Central \\
\hline Arabidopsis croatica (Schott) O'Kane \& Al-Shehbaz & $(2 n=16)$ & Croatia \\
\hline \multicolumn{3}{|l|}{ Allopolyploid taxa } \\
\hline Arabidopsis kamchatica (Fisch. Ex DC.) O'Kane \& Al-Shehbaz & $(2 n=32)$ & Boreal Alasca, Canada, E Siberia, Russian Far East, Korea, Japan, \\
\hline \multicolumn{3}{|l|}{ Taiwan } \\
\hline $\begin{array}{l}\text { Arabidopsis kamchatica subsp. kawasakiana (Makino) } \\
\text { Shimizu \& Kudoh }\end{array}$ & $(2 n=32)$ & Japan, winterannual (coastal, lowland) \\
\hline Arabidopsis suecica (Fr.) Norrl. & $(2 n=26)$ & Fennoscandinavia and the Baltic region \\
\hline
\end{tabular}

Species diversity of Arabidopsis thaliana's relatives. Information on taxonomy, chromosome number, ploidy level and geographic distribution is provided. 
Russian Arabidopsis taxa [17], however, may be considered more carefully in future, based on current morphological and molecular analysis (Koch et al., unpublished data).

Monophyly is generally accepted among Arabidopsis taxa by plant scientists at present. However, considering that $A$. thaliana is a model system taxonomic recognition of new species as Arabidopsis is acknowledged much faster than comparable systematic-taxonomic changes in other genera. One such contrary example from the Brassicaceae family is the genus Noccaea which includes important model species for heavy metal tolerance and hyperaccumulation. Noccaea caerulescens required more than 30 years to be recognized appropriately within the correct evolutionary framework [20,21]. Systematics and taxonomy in the genus Arabidopsis is thus ever-debatable and in constant need of further improvement.

\section{Developing a comprehensive systematic framework}

To date there is limited genetic information across the entire genus which allows for adequate taxonomic and systematic comparison. The first study highlighting centers of genetic variation in Europe for the main evolutionary lineages also provided evidence for extensive shared plastidic variation among species [22]. The female component of nuclear-encoded self-incompatibility genes (SI alleles at the SRK locus) also revealed trans-specific polymorphism among some of the same species [23].

Some major evolutionary lineages have been identified in the Arabidopsis genus [18,22], namely the following groups: A. halleri, A. lyrata and A. arenosa. Three other genetically isolated diploid species have been identified, A. croatica, A. cebennensis and A. pedemontana. A few allopolyploids are also well studied: $A$. suecica with $A$. arenosa and $A$. thaliana as parental species [24,25], and A. kamchatica with A. lyrata and A. halleri (subsp. gemmifera) as parents [26-28]. Another taxonomically not yet introduced tetraploid taxon (close to A. lyrata) is found in Lower Austria, which is either the result of hybridization and genome doubling between $A$. arenosa and A. lyrata (allopolyploidy), or genome duplication of diploid $A$. lyrata (autopolyploid) with subsequent introgression from tetraploid $A$. arenosa [29].

For some of these major lineages and their subspecies there are more detailed genetic studies available covering either a broader geographic scale or larger sets of taxa. For A. halleri it has been shown that all five subspecies are closely related to each other, and that one major center of genetic diversity is located in the Eastern Austrian Alps [22]. It has also been concluded for A. halleri that metallicolous populations have been founded separately from distinct non-metallicolous populations without suffering from founder effects [30]. The same authors provided a comprehensive phylogeographic scenario [31]; and although the accessions studied were not characterized taxonomically, many helpful comments linking taxonomy with genetic data were provided. For A. lyrata there are several studies available showing general phylogeographic patterns and hybrid speciation on a large scale $[26,27]$. Local-scale phylogeographic studies in North America highlighted switches in mating system [32,33]. Populationbased analysis with a few selected populations provided the first evidence for population genetic structure at varying geographic scales [34-36]. At a more local scale and focusing on different aspects of adaptation there are numerous contributions covering A. lyrata [37-39], and comprehensive reviews have recently been presented to summarize many more aspects $[1,40]$. There is very limited information regarding $A$. arenos $a$, one of the most diverse evolutionary lineages in Arabidopsis [22], with only one phylogeographic-systematic study at a broad geographic scale [19]. Nevertheless, $A$. arenosa has proven to be an excellent model to study the formation and evolution of allopolyploids [41,42] and plant adaptation [43,44].

A recently published review [45] emphasized the need for all-encompassing evolutionary studies within the genus Arabidopsis that provide a broader framework on genus-wide genetic diversity and differentiation, in order to enable researchers to study molecular mechanisms of speciation-related processes in interspecific comparative approaches. Our goal here was to provide a reliable phylogenetic-systematic base line using ribosomal DNA sequence variation from the internal transcribed spacers 1 and 2 and the trnLF region of the plastid genome [22]. These data were combined with population genetic variation based on a set of nuclear-encoded microsatellite loci shown to be highly sensitive for resolving Arabidopsis lineages [29]. Finally, since genome size and chromosome numbers are important cytological characters that significantly influence various organismal traits, we conducted a comprehensive scan of cytological variation via the homoploid nuclear DNA content within and among the principal gene pools in Arabidopsis.

Here we explore the gene pools of Arabidopsis taxa using a battery of molecular markers and their cytology to identify clearly genetically distinct units over their entire geographic distribution, develop a schematic phylogeographic-systematic scenario based on this data and lastly, comment on any discrepancies between these resolved gene pools and existing taxonomic identifiers.

\section{Results}

Our results indicate the existence of several major gene pools or species groups; confirming several taxonomically recognized species and subspecies (Figure 1). However, it is also obvious that gene flow and/or shared ancestry blur some distinct evolutionary units in several cases, both between ploidy levels and among species. 


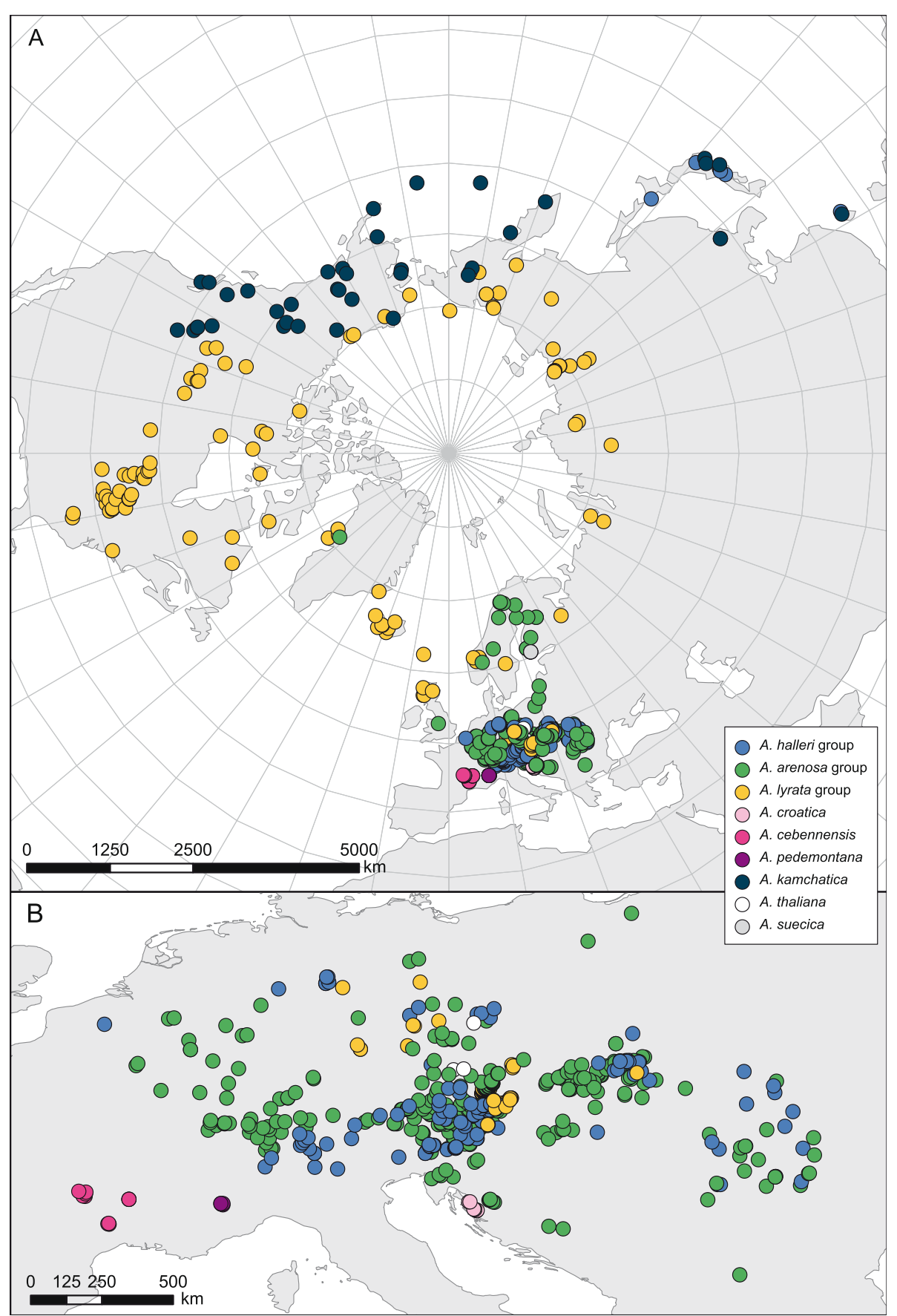

Figure 1 Sampling distribution. Geographic distribution of the analyzed Arabidopsis taxa. A) Circumpolar perspective of sample distribution, B) European sampling of accessions. Detailed accession data are provided with Additional file 5.

The number of single nucleotide polymorphisms (SNPs) was not sufficient to resolve taxa below the species level, most likely because the genus' radiation within the last 2.5 million years is too recent.

\section{ITS sequence data recognize major gene pools}

The recognition of major gene pools or evolutionary lineages is best illustrated by the SplitsTree analysis based on the ITS (Figure 2). Six major groups with deep splits were detected: 1) A. halleri and its subspecies, 2) A. lyrata and its segregates and subspecies, including all $A$. kamchatica accessions, 3) $A$. arenosa and its various segregates, subspecies and related taxa (see Tables 1 and 2), 4) diploid A. croatica, which is closest to A. arenosa, 5) A. cebennensis, which is sister to 6) A. pedemontana. Notably, the ITS failed to resolve taxa within evolutionary 


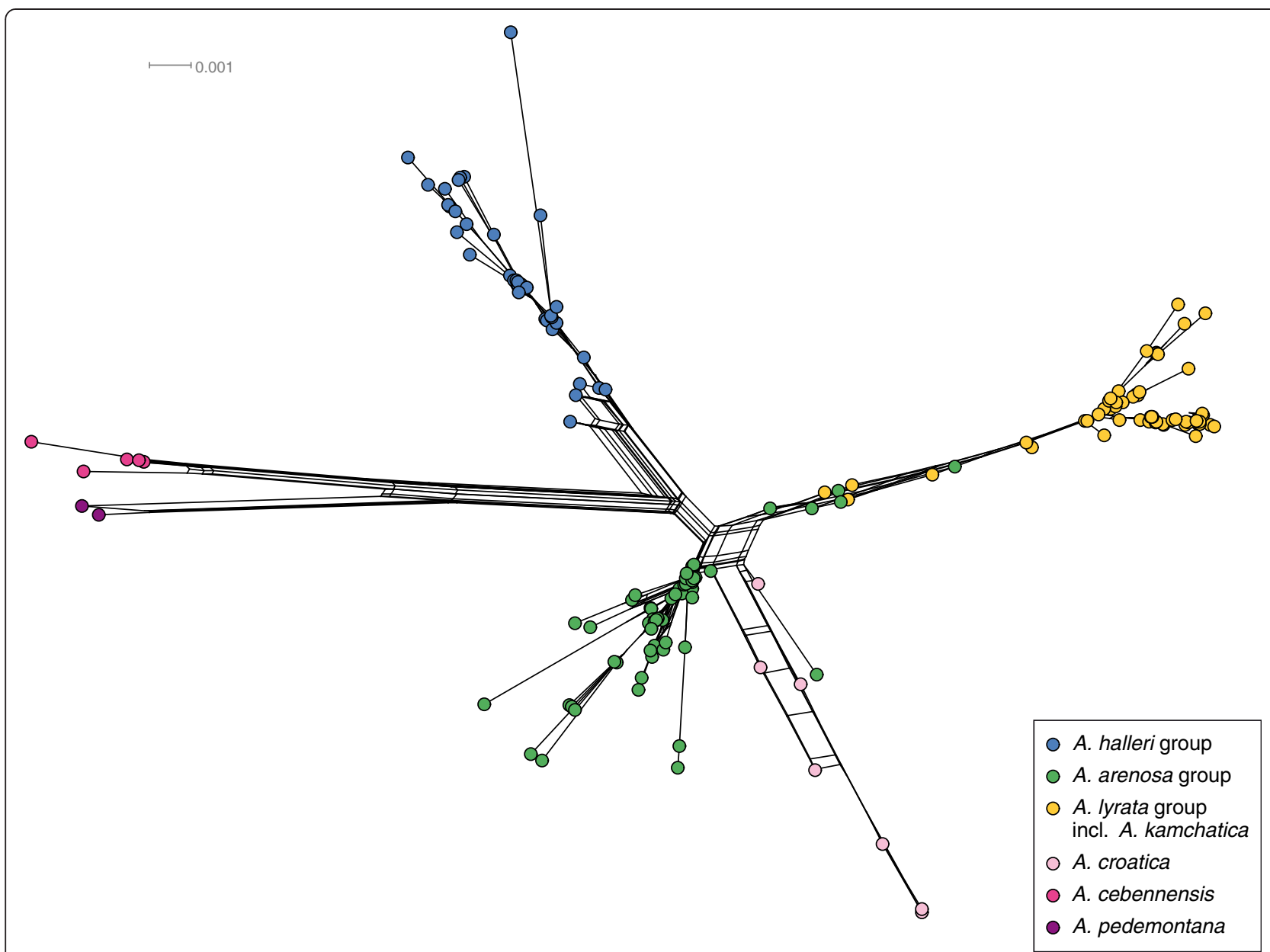

Figure 2 SplitsTree analysis of ITS data. Results of the SplitsTree analysis [80] of ITS DNA sequence data. Detailed accession data and ITS type definition are provided with Additional file 5.

Table 2 Estimation of absolute genome size data of Arabidopsis taxa

\begin{tabular}{|c|c|c|c|c|}
\hline & $\mathbf{N}$ & $1 C x$-value (pg) (SD) & Expected genome size & Calculated genome size $^{1}$ \\
\hline Arabidopsis thaliana (Columbia) $(2 x)$ & 4 & $0.173(0.010)$ & $135 \mathrm{Mbp}^{(1)}$ & ${ }^{(1)}$ set as reference \\
\hline Arabidopsis croatica $(2 \times)$ & 2 & $0.225(0.007)$ & & $176 \mathrm{Mbp}$ \\
\hline Arabidopsis arenicola $(2 x)$ & 4 & $0.260(0.008)$ & & $203 \mathrm{Mbp}$ \\
\hline Arabidopsis lyrata (2x) (Europe) & 4 & $0.270(0.005)$ & & $210 \mathrm{Mbp}$ \\
\hline Arabidopsis lyrata (2x) (North America) & 8 & $0.274(0.007)$ & $207 \mathrm{Mbp}^{(2)}$ & $214 \mathrm{Mbp}$ \\
\hline Arabidopsis lyrata (4X) & 4 & $0.238(0.005)$ & & $371 \mathrm{Mbp}$ \\
\hline Arabidopsis halleri ssp. halleri $(2 x)$ & 10 & $0.266(0.010)$ & & $207 \mathrm{Mbp}$ \\
\hline Arabidopsis halleri ssp. gemmifera $(2 x)$ & 6 & $0.270(0.004)$ & & $211 \mathrm{Mbp}$ \\
\hline Arabidopsis kamchatica (4X) & 2 & $0.235(0.007)$ & & $367 \mathrm{Mbp}$ \\
\hline Arabidopsis arenosa $(4 \times)$ & 6 & $0.237(0.005)$ & & $370 \mathrm{Mbp}$ \\
\hline Arabidopsis cebennensis $(2 x)$ & 22 & $0.281(0.010)$ & & $219 \mathrm{Mbp}$ \\
\hline Arabidopsis pedemontana $(2 X)$ & 6 & $0.277(0.005)$ & & $216 \mathrm{Mbp}$ \\
\hline
\end{tabular}

Genome sizes measured as 1Cx-values in pg. Arabidopsis thaliana was used as absolute reference of genome size ('135 Mbp, TAIR: http://www.arabidopsis.org) with standard deviation (SD) provided. All genome size data were extrapolated as haploid genome size (1C) accordingly to achieve absolute genome sizes in Mbp. Arabidopsis lyrata from North America served as second and independent control since its genome has been also sequenced and fully annotated ${ }^{2}$ (207 Mbp [46]). Ploidy level is given in brackets after the respective taxon name. (N: number of individuals analyzed). 
lineages. For example, a few $A$. arenosa accessions cluster within $A$. lyrata or $A$. croatica (one accession). This is best explained by interploidy and interspecies gene flow and/or shared ancestry, as commented on earlier $[18,19]$. All analyzed $A$. suecica accessions carried ITS types, which clustered with $A$. thaliana ITS types (results not shown). The complete alignment can be viewed in Additional file 1.

\section{Nuclear DNA content supports the distinction of major ITS gene pools}

The major gene pools identified by ITS sequences were also significantly differentiated by their homoploid nuclear DNA content (Figure 3 ). Disregarding $A$. thaliana, with a basic chromosome number of $\mathrm{n}=5$ ( $1 \mathrm{C}$ value of about $0.17 \mathrm{pg}$ ) and on average $47 \%$ less DNA than the other diploid accessions, the homoploid nuclear DNA content varied 1.66-fold among diploid and 1.14-fold among tetraploid accessions, respectively. The differences among major gene pools were highly significant among diploid $\left(\mathrm{F}_{5,96}=212, \mathrm{p}<0.0001\right)$ and marginally significant among tetraploid $\left(\mathrm{F}_{1,39}=4.8, \mathrm{p}=0.03\right)$ accessions. At the diploid level, accessions of $A$. arenosa possessed the lowest nuclear DNA content, followed by A. croatica (5\% larger DNA content than $A$. arenosa, but not significant), $A$. lyrata (17\%), A. halleri (23\%) and, finally, A. pedemontana (42\%) and $A$. cebennensis (55\% larger DNA content than $A$. arenosa; Figure 3$)$. Interestingly, $A$. croatica and $A$. arenosa was the only species pair with non-significant differentiation in nuclear DNA contents. Among tetraploids, A. lyrata exhibited on average $5 \%$ lower nuclear DNA content than $A$. arenosa, although it still fell within the range of $A$. arenosa variation.

In contrast to among-group nuclear DNA content, variation was markedly reduced within the major gene pools and differences among accessions were minimal (the DNA content varied 1.18-fold, 1.1-fold and 1.14fold, within diploid A. lyrata, A. arenosa, and A. halleri gene pools, respectively; and 1.01-fold and 1.14-fold within tetraploid $A$. lyrata and $A$. arenosa, respectively). In tetraploids, the variation was $1.01-$ fold and 1.14-fold among $A$. lyrata and $A$. arenosa accessions, respectively.

Absolute genome size estimates are also provided for all taxa in Table 2 in a Brassicaceae-wide screen. The $1 C$-value of $A$. thaliana ecotype Columbia is about $0.17 \mathrm{pg}$. The estimated physical size of its genome is currently about $135 \mathrm{Mbp}$, (TAIR, http://www.arabidopsis.org/). Our estimated $1 \mathrm{C}$-value of $0.274 \mathrm{pg}$ for North American A. lyrata indicates a respective genome size of approximately $214 \mathrm{Mbp}$ and is very close to the published physical size (207 Mbp) of the A. lyrata genome [46]. The discrepancy of about $5 \%$ could be explained by missing sequence data from centromeric regions.

\section{Chloroplast sequence data recognize some major gene pools but indicates shared polymorphism}

In contrast to the ITS, plastid trnLF sequences did not fully resolve all evolutionary lineages. The TCS network recognized 71 suprahaplotypes and two additional suprahaplotypes from $A$. thaliana/A. suecica (Figure 4). Central suprahaplotypes in the network with the highest frequency of occurrence (A, B, C, D, E) were largely shared among lineages (as defined by ITS). In agreement with placement of the root (A. thaliana), haplotype A was the most ancestral (occurring also with the highest frequency), and it was shared among all lineages. Suprahaplotypes B and $\mathrm{C}$ were shared among the three major lineages (A. lyrata, A. arenosa, and $A$. halleri), and suprahaplotypes D and $\mathrm{E}$ were shared by $A$. halleri and $A$. arenosa only. Insufficient resolution in the chloroplast suggests the presence of shared ancestral gene pools and subsequent incomplete lineage sorting [29]; and/or hybridization and introgression which in some cases resulted in stable allopolyploids (e.g. A. kamchatica, A. suecica). In particular, hybridization and introgression may not be resolved by ITS data because of rapid and ongoing concerted evolution $[27,47]$. Past interploidy and interspecific gene flow has been demonstrated among European Arabidopsis species [48], and introgression zones can indeed have larger geographic extension and long-term persistence [29]. One notable detail taken from the TCS network is that connecting haplotypes were rarely missing. This might be anindicator for (overall) limited bottlenecks and large past effective population sizes [49]. The trnLF alignment is shown in Additional file 2, and a summary of all suprahaplotypes and their distribution among taxa is shown in Additional file 3.

\section{Microsatellite analyses characterize distinctive taxa and cytotypes}

A summary statistics table for microsatellite alleles within the various taxa is given with Table 3, and displays total number of alleles, mean number of alleles per locus, number of unique alleles, and number of rare alleles $(<5 \%)$. These data show that tetraploids have a significantly higher number of alleles per locus per individual (normally exceeding 2 alleles per locus) ( $\mathrm{p}<0.001)$ than diploids, as one would expect. The highest numbers of total alleles were found within widely distributed diploid A. lyrata subsp. petraea, tetraploid $A$. arenosa subsp. arenosa and subsp. borbasii, but also with diploid $A$. carpatica and tetraploid A. petrogena subsp. exoleta, which highlights the importance of the $A$. arenosa gene pool as highly diverse [22]. Accordingly, the same taxa did not only carry the highest numbers of unique alleles but also rare alleles (frequency $5 \%$ and lower in the whole dataset). It is also demonstrated by the summary statistics that local endemics such as $A$. pedemontana, A. cebennensis, or $A$. croatica 


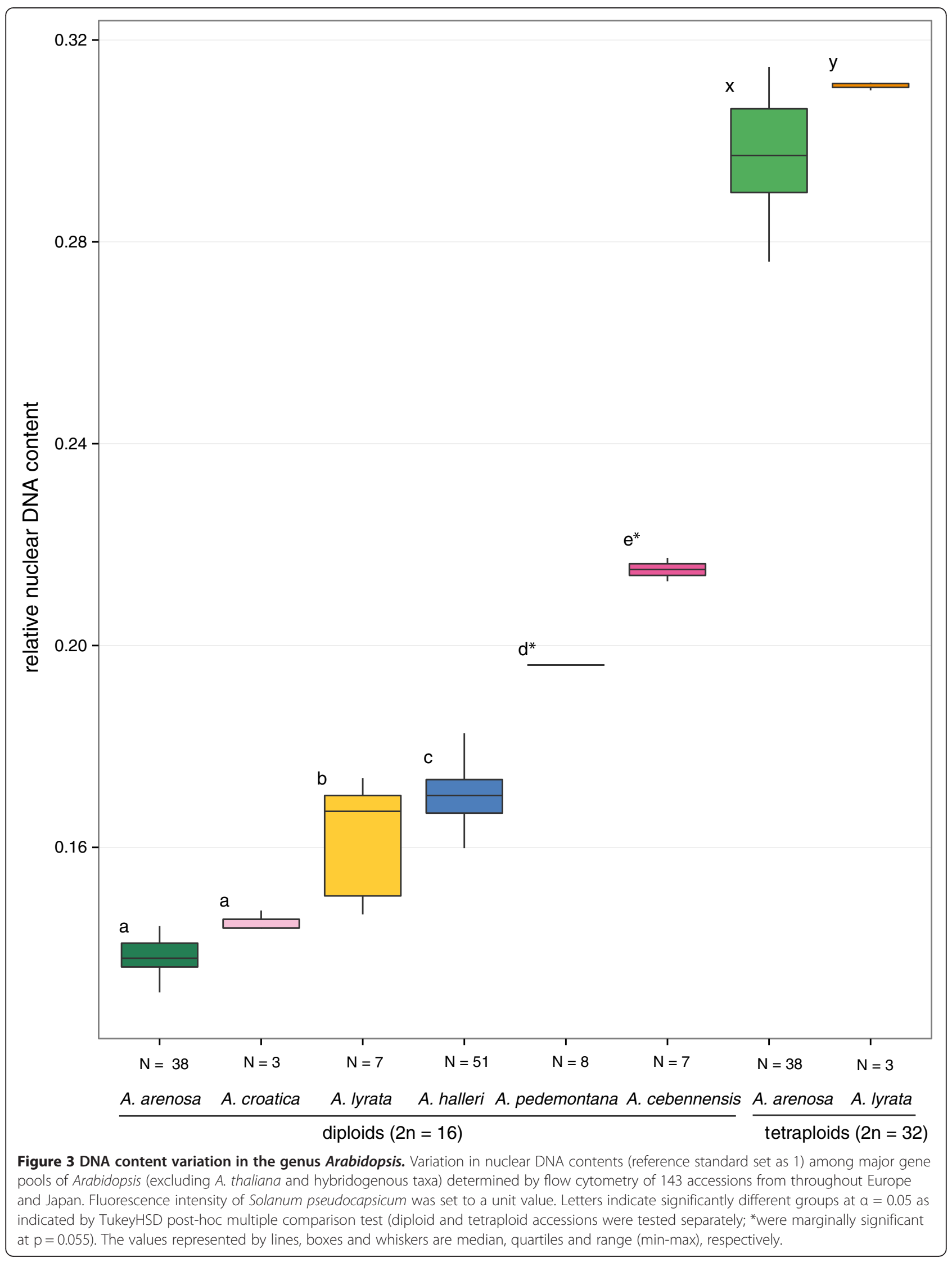




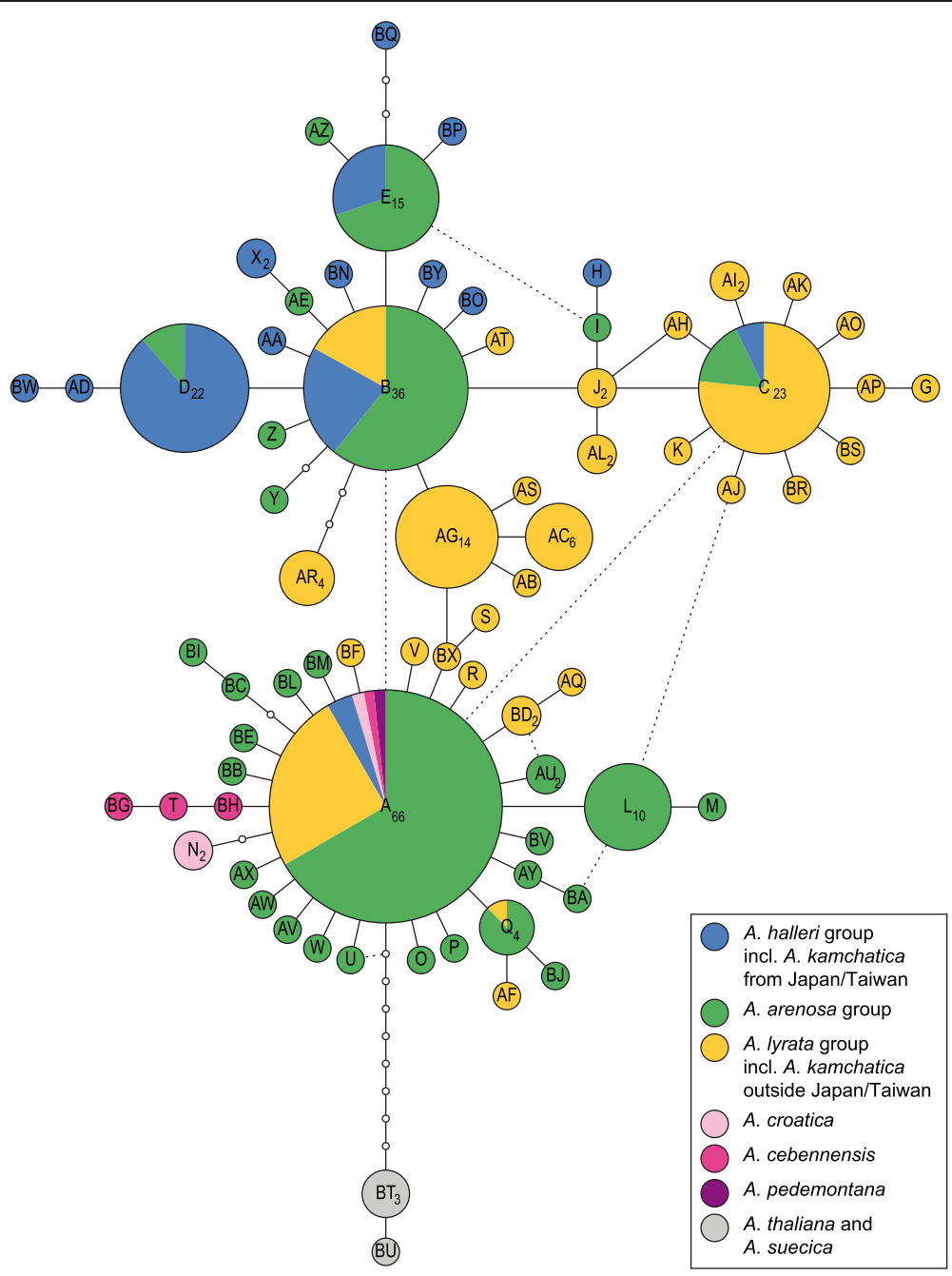

Figure 4 Chloroplast DNA type network analysis in the genus Arabidopsis. The chloroplast DNA (trnLF) network from the TCS analysis [76] recognized $71 \mathrm{cpDNA}$ suprahaplotypes and two additional suprahaplotypes from $A$. thaliana/A. suecica. The size of the circle represents the number of sequence types within the suprahaplotype. Dash lines indicate not significant connections as revealed with maximum-likelihood tree building analysis. Detailed accession data are provided with Additional file 5.

(all of them endangered and highly protected) had much lower numbers for any genetic scoring value (Tables 3 and 4). This was also true for North American A. lyrata subsp. lyrata and A. arenicola.

Structure analysis combining diploids and tetraploids recognized five major groups: 1) A. lyrata, 2) A. arenosa (including A. croatica), 3) A. halleri, 4) A. pedemontana and 5) A. cebennensis (Figure 5B, upper part, corresponding Structure-sum analyses provided in Additional file 4). Two of these groups (A. lyrata and A. arenosa) consist of diploids and tetraploids, and Structure was rerun to analyze these two groups separately (Figure 5B, lower part). In this separate analysis, $A$. lyrata could be split into $K=3$ populations I) North American A. lyrata subsp. lyrata and A. arenicola, II) diploid A. umbrosa and tetraploid
A. septentrionalis, and III) European A. lyrata subsp. petraea (irrespective of ploidy level, Figure $5 \mathrm{~B}$, lower part).

A. arenosa, on the other hand, fell into $K=4$ populations; all tetraploid $A$. arenosa including tetraploid $A$. neglecta and $A$. petrogena are set apart from the diploid taxa. Vice versa the diploid A. carpatica and diploid A. petrogena formed distinct groups, respectively. The remaining diploids A. neglecta, A. croatica and A. nitida are combined to form one group. Interestingly, Structure was indifferent to the level of ploidy and the results are total in agreement with the ITS data. However, the initial round of analysis (combining diploids and tetraploids, Figure 5B) produced minor incongruencies such as the occurrence of distinct $A$. pedemontana genetic variation 
Table 3 Arabidopsis microsatellite genetic variation

\begin{tabular}{|c|c|c|c|c|c|c|c|}
\hline Taxon & Ploidy & $\begin{array}{l}\text { Mating } \\
\text { system }\end{array}$ & $\begin{array}{l}\text { Individuals } \\
\text { (populations) }\end{array}$ & $\begin{array}{l}\text { No. of } \\
\text { alleles }\end{array}$ & $\begin{array}{l}\text { Mean no. of alleles } \\
\text { per locus (SD) }\end{array}$ & $\begin{array}{l}\text { No. of unique } \\
\text { alleles }\end{array}$ & $\begin{array}{l}\text { No. of rare } \\
\text { alleles }(5 \%)\end{array}$ \\
\hline A. arenicola & Diploid & SC & $19(14)$ & 17 & $1.04(0.10)$ & - & - \\
\hline A. lyrata subsp. lyrata & Diploid & $\mathrm{SI} / \mathrm{SC}^{1}$ & $57(29)$ & 38 & $1.18(0.16)$ & - & - \\
\hline A. petraea susbp. umbrosa & Diploid & Unknown & $25(16)$ & 29 & $1.20(0.26)$ & - & 2 \\
\hline A. petraea subsp. septentrionalis & Tetraploid & Unknown & $8(8)$ & 36 & $1.63(0.31)$ & 2 & 2 \\
\hline A. lyrata subsp. petraea & Diploid & $\mathrm{SI}$ & $187(13)$ & 89 & $1.46(0.19)$ & 10 & 13 \\
\hline A. lyrata subsp. petraea & Tetraploid & $\mathrm{SI}$ & $25(5)$ & 57 & $1.93(0.37)$ & - & - \\
\hline A. arenosa subsp. arenosa & Tetraploid & $\mathrm{SI}$ & $76(13)$ & 94 & $2.31(0.33)$ & 2 & 5 \\
\hline A. arenosa subsp. arenosa var. intermedia & Tetraploid & $\mathrm{SI}$ & $14(4)$ & 44 & $2.19(0.27)$ & - & - \\
\hline A. arenosa subsp. borbasii & Tetraploid & $\mathrm{SI}$ & $160(22)$ & 111 & $2.30(0.33)$ & 7 & 9 \\
\hline A. carpatica & Diploid & SI & $113(9)$ & 104 & $1.59(0.19)$ & 6 & 10 \\
\hline A. petrogena subsp. petrogena & Diploid & $\mathrm{SI}$ & $73(7)$ & 73 & $1.53(0.20)$ & - & 3 \\
\hline A. petrogena subsp. exoleta & Tetraploid & $\mathrm{SI}$ & $56(11)$ & 83 & $2.22(0.36)$ & 1 & 5 \\
\hline A. neglecta subsp. neglecta & Diploid & $\mathrm{SI}$ & $35(5)$ & 51 & $1.51(0.21)$ & 1 & 3 \\
\hline A. neglecta subsp. robusta & Tetraploid & $\mathrm{SI}$ & $8(1)$ & 39 & $2.24(0.23)$ & - & 2 \\
\hline A. nitida & Diploid & $\mathrm{SI}$ & $22(4)$ & 59 & $1.54(0.22)$ & 3 & 3 \\
\hline A. croatica & Diploid & $\mathrm{SI}$ & $15(3)$ & 26 & $1.33(0.19)$ & 1 & 1 \\
\hline A. halleri subsp. dacica & Diploid & $\mathrm{SI}$ & $3(3)$ & 15 & $1.53(0.31)$ & - & - \\
\hline A. halleri subsp. halleri & Diploid & SI & 199 (19) & 59 & $1.37(0.19)$ & 6 & 7 \\
\hline A. halleri subsp. ovirensis & Diploid & $\mathrm{SI}$ & $24(4)$ & 18 & $1.31(0.16)$ & 1 & 1 \\
\hline A. halleri subsp. tatrica & Diploid & SI & $25(7)$ & 40 & $1.37(0.14)$ & - & 1 \\
\hline A. halleri subsp. gemmifera & Diploid & $\mathrm{SI}$ & $8(5)$ & 15 & $1.10(0.15)$ & - & - \\
\hline A. cebennensis & Diploid & $\mathrm{SI}$ & $153(11)$ & 23 & $1.17(0.14)$ & - & - \\
\hline A. pedemontana & Diploid & $\mathrm{SI}$ & $40(9)$ & 22 & $1.31(0.18)$ & - & 1 \\
\hline
\end{tabular}

Summary table of analyzed individuals and populations of the various Arabidopsis taxa for microsatellite variation. Information on ploidy level, mating system variation (own data and literature survey) and some summary statistics are provided. SC: self-compatible, SI: self-incompatible.

${ }^{1} \mathrm{SC}$ populations of North American A. lyrata subsp. lyrata are not considered here.

${ }^{2}$ Respectively two loci in tetraploids.

in other species such as A. umbrosa. This similarity is immediately eliminated when increasing $K$ to the next higher values (data not shown).

When the Structure analysis is strictly confined to each ploidy level separately, the results are more congruent with better resolution (Figure 5A). In the diploid $A$. lyrata dataset $(K=2 / 3)$, A. arenicola was again not separated from $A$. lyrata subsp. lyrata, but $A$. umbrosa and $A$. lyrata subsp. petraea were still distinguished from each other (Figure 5A, upper part). Note that we report multiple $K$ 's here and their corresponding barplots in Figure 5 to reflect the fact that delta $K$ was frequently either very similar between two independent runs, or because the less optimal $K$ was more biologically meaningful. Both the optimal $K$, and the next-best optimal $K$ in the Structure analysis are thus reported.

The diploid $A$. arenosa group was structured with $K=3 / 4$, and $A$. carpatica, A. petrogena subsp. petrogena, A. neglecta subsp. neglecta and A. croatica were significantly recognized. Arabidopsis nitida (only few samples analyzed) was less clearly recognized. The five subspecies of $A$. halleri $(K=4)$ were grouped with some genetic clusters that distinguished a) A. halleri subsp. ovirensis, b) A. halleri subsp. tatrica/gemmifera, and c) a more complex and mixed cluster of A. halleri subsp. halleri (Figure 5A, upper part). With subsp. dacica the results should be interpreted with caution since only three individuals were analyzed. In summary the structure within $A$. halleri subsp. halleri is not clear and possibly indicates the need for taxonomic re-evaluation after comprehensive phylogeographic analysis [30,31].

Analysis of the tetraploid dataset resulted in two unambiguously detectable genetic clusters only (Figure 5C, upper part) and distinguished $A$. lyrata from $A$. arenosa. However, it is interesting to see that $A$. septentrionalis carried approximately $50 \%$ genetic admixture from the $A$. arenosa genetic cluster. When analyzing tetraploid $A$. lyrata separately $(K=2)$, again $A$. septentrionalis was significantly different from tetraploid $A$. lyrata subsp. petraea from Scotland and Austria. In contrast, 
Table 4 Gene diversity statistics of microsatellites, ITS and cpDNA variation

\begin{tabular}{|c|c|c|c|c|c|c|c|c|c|}
\hline & \multirow[b]{2}{*}{ Ploidy } & \multicolumn{2}{|c|}{ Microsatellites } & \multicolumn{3}{|c|}{ ITS haplotypes } & \multicolumn{3}{|c|}{ trnLF haplotypes } \\
\hline & & $\begin{array}{l}\text { Individuals } \\
\text { analyzed }\end{array}$ & $\begin{array}{l}\text { Nei's gene } \\
\text { diversity (SD) }\end{array}$ & $\begin{array}{l}\text { Individuals } \\
\text { analyzed }\end{array}$ & $\begin{array}{l}\text { Nucleotide } \\
\text { diversity } \\
\left(\pi \times 10^{-2}\right) \text { (SD) }\end{array}$ & $\begin{array}{l}\text { Nei's gene } \\
\text { diversity (SD) }\end{array}$ & $\begin{array}{l}\text { Individuals } \\
\text { analyzed }\end{array}$ & $\begin{array}{l}\text { Nucleotide } \\
\text { diversity } \\
\left(\pi \times 10^{-2}\right) \text { (SD) }\end{array}$ & $\begin{array}{l}\text { Nei's gene } \\
\text { diversity (SD) }\end{array}$ \\
\hline A. lyrata group & & $288(85)$ & $0.562(0.312)$ & $126(92)$ & $0.248(0.168)$ & $0.797(0.025)$ & $176(101)$ & $0.224(0.150)$ & $0.751(0.024)$ \\
\hline A. arenicola & $2 x$ & $19(14)$ & $0.205(0.156)$ & $17(16)$ & $0.139(0.117)$ & $0.323(0.135)$ & $17(15)$ & $0.035(0.047)$ & $0.117(0.101)$ \\
\hline $\begin{array}{l}\text { A. lyrata subsp. } \\
\text { lyrata }\end{array}$ & $2 x$ & $57(29)$ & $0.378(0.225)$ & $37(21)$ & $0.014(0.030)$ & $0.516(0.085)$ & $54(26)$ & $0.058(0.061)$ & $0.380(0.065)$ \\
\hline $\begin{array}{l}\text { A. petraea subsp. } \\
\text { umbrosa }\end{array}$ & $2 x$ & $25(16)$ & $0.468(0.272)$ & $30(18)$ & $0.154(0.118)$ & $0.675(0.061)$ & $28(18)$ & $0.362(0.225)$ & $0.738(0.053)$ \\
\hline $\begin{array}{l}\text { A. petraea subsp. } \\
\text { septentrionalis }\end{array}$ & $4 \times$ & $8(8)$ & not calculated & $10(10)$ & $0.030(0.046)$ & $0.200(0.154)$ & $9(9)$ & $0.323(0.223)$ & $0.694(0.147)$ \\
\hline $\begin{array}{l}\text { A. lyrata subsp. } \\
\text { petraea }\end{array}$ & $2 x$ & $187(13)$ & $0.556(0.309)$ & $31(26)$ & $0.025(0.039)$ & $0.898(0.030)$ & $61(29)$ & $0.229(0.154)$ & $0.766(0.042)$ \\
\hline $\begin{array}{l}\text { A. lyrata subsp. } \\
\text { petraea }\end{array}$ & $4 \times$ & $25(5)$ & not calculated & $1(1)$ & 0.000 & $1.000(0.000)$ & $7(4)$ & $0.241(0.185)$ & $0.714(0.180)$ \\
\hline A. arenosa group & & $258(79)$ & $0.560(0.311)$ & $247(181)$ & $0.138(0.107)$ & $0.803(0.024)$ & $568(263)$ & $0.171(0.123)$ & $0.585(0.023)$ \\
\hline $\begin{array}{l}\text { A. arenosa subsp. } \\
\text { arenosa }\end{array}$ & $4 \times$ & $76(13)$ & not calculated & $23(23)$ & $0.129(0.106)$ & $0.806(0.061)$ & $32(28)$ & $0.163(0.122)$ & $0.485(0.107)$ \\
\hline $\begin{array}{l}\text { A. arenosa var. } \\
\text { intermedia }\end{array}$ & $4 \times$ & $14(4)$ & not calculated & $4(3)$ & 0.000 & $1.000(0.176)$ & $6(5)$ & $0.149(0.133)$ & $0.333(0.215)$ \\
\hline $\begin{array}{l}\text { A. arenosa subsp. } \\
\text { borbasii }\end{array}$ & $4 \times$ & $160(22)$ & not calculated & $173(120)$ & $0.065(0.066)$ & $0.748(0.033)$ & $391(167)$ & $0.142(0.107)$ & $0.503(0.029)$ \\
\hline A. carpatica & $2 x$ & $113(9)$ & $0.554(0.309)$ & $8(6)$ & $0.065(0.075)$ & $0.750(0.139)$ & $51(14)$ & $0.282(0.181)$ & $0.752(0.046)$ \\
\hline A. petrogena & $2 x$ & $73(7)$ & $0.512(0.289)$ & $5(4)$ & $0.399(0.298)$ & $1.000(0.298)$ & $37(20)$ & $0.052(0.058)$ & $0.348(0.077)$ \\
\hline $\begin{array}{l}\text { A. petrogena subsp. } \\
\text { exoleta }\end{array}$ & $4 \times$ & $56(11)$ & not calculated & $8(6)$ & $0.345(0.241)$ & $0.928(0.084)$ & $8(6)$ & $0.341(0.238)$ & $0.892(0.085)$ \\
\hline $\begin{array}{l}\text { A. neglecta subsp. } \\
\text { neglecta }\end{array}$ & $2 x$ & $35(5)$ & $0.451(0.262)$ & $8(5)$ & $0.323(0.229)$ & $0.928(0.084)$ & $16(5)$ & $0.111(0.097)$ & $0.450(0.150)$ \\
\hline $\begin{array}{l}\text { A. neglecta subsp. } \\
\text { robusta }\end{array}$ & $4 \times$ & $8(1)$ & not calculated & $6(3)$ & 0.000 & $0.600(0.215)$ & $6(3)$ & $0.099(0.101)$ & $0.333(0.215)$ \\
\hline A. nitida & $2 x$ & $22(4)$ & $0.635(0.354)$ & $4(4)$ & $0.384(0.309)$ & $1.000(0.176)$ & $11(6)$ & $0.282(0.196)$ & $0.709(0.099)$ \\
\hline A. croatica & $2 x$ & $15(3)$ & $0.374(0.228)$ & $8(7)$ & $0.384(0.263)$ & $1.000(0.062)$ & $10(9)$ & $0.159(0.129)$ & $0.533(0.094)$ \\
\hline A. halleri group & & $259(38)$ & $0.427(0.254)$ & $103(90)$ & $0.159(0.118)$ & $0.901(0.020)$ & $94(83)$ & $0.268(0.173)$ & $0.712(0.030)$ \\
\hline $\begin{array}{l}\text { A. halleri subsp. } \\
\text { dacica }\end{array}$ & $2 x$ & $3(3)$ & $0.533(0.380)$ & $8(7)$ & $0.049(0.063)$ & $0.928(0.084)$ & $8(7)$ & $0.213(0.165)$ & $0.464(0.200)$ \\
\hline $\begin{array}{l}\text { A. halleri subsp. } \\
\text { halleri }\end{array}$ & $2 x$ & 199 (19) & $0.392(0.237)$ & $67(61)$ & $0.036(0.047)$ & $0.858(0.029)$ & $62(58)$ & $0.236(0.158)$ & $0.670(0.049)$ \\
\hline $\begin{array}{l}\text { A. halleri subsp. } \\
\text { ovirensis }\end{array}$ & $2 x$ & $24(4)$ & $0.330(0.204)$ & $5(4)$ & $0.122(0.122)$ & $0.900(0.161)$ & $2(1)$ & 0.000 & 0.000 \\
\hline $\begin{array}{l}\text { A. halleri subsp. } \\
\text { tatrica }\end{array}$ & $2 x$ & $25(7)$ & $0.408(0.242)$ & $13(10)$ & $0.023(0.039)$ & $0.730(0.096)$ & $12(10)$ & $0.364(0.238)$ & $0.727(0.113)$ \\
\hline $\begin{array}{l}\text { A. halleri subsp. } \\
\text { gemmifera }\end{array}$ & $2 x$ & $8(5)$ & $0.301(0.205)$ & $9(7)$ & $0.570(0.363)$ & $0.916(0.092)$ & $9(6)$ & 0.000 & 0.000 \\
\hline A. umezawana & $?$ & 0 & not calculated & $1(1)$ & 0.000 & $1.000(0.000)$ & $1(1)$ & 0.000 & $1.000(0.000)$ \\
\hline A. cebennensis & $2 x$ & $153(11)$ & $0.189(0.130)$ & $8(6)$ & $0.185(0.150)$ & $0.785(0.150)$ & $148(12)$ & $0.174(0.125)$ & $0.702(0.018)$ \\
\hline A. pedemontana & $2 x$ & $40(9)$ & $0.259(0.167)$ & $2(2)$ & $0.312(0.382)$ & $1.000(0.500)$ & $9(2)$ & 0.000 & 0.000 \\
\hline
\end{tabular}

Nei's Gene and nucleotide diversity [89] of microsatellite, ITS and cpDNA genetic variation among the various taxa. The number of individuals analyzed is indicated with respective number of populations in brackets. Standard deviation of mean genetic diversity is given in brackets.

Gene diversity statistics for microsatellite variation among tetraploid populations was not calculated, but respective data are analyzed and displayed with hierarchical Structure analysis (see Figure 5). 


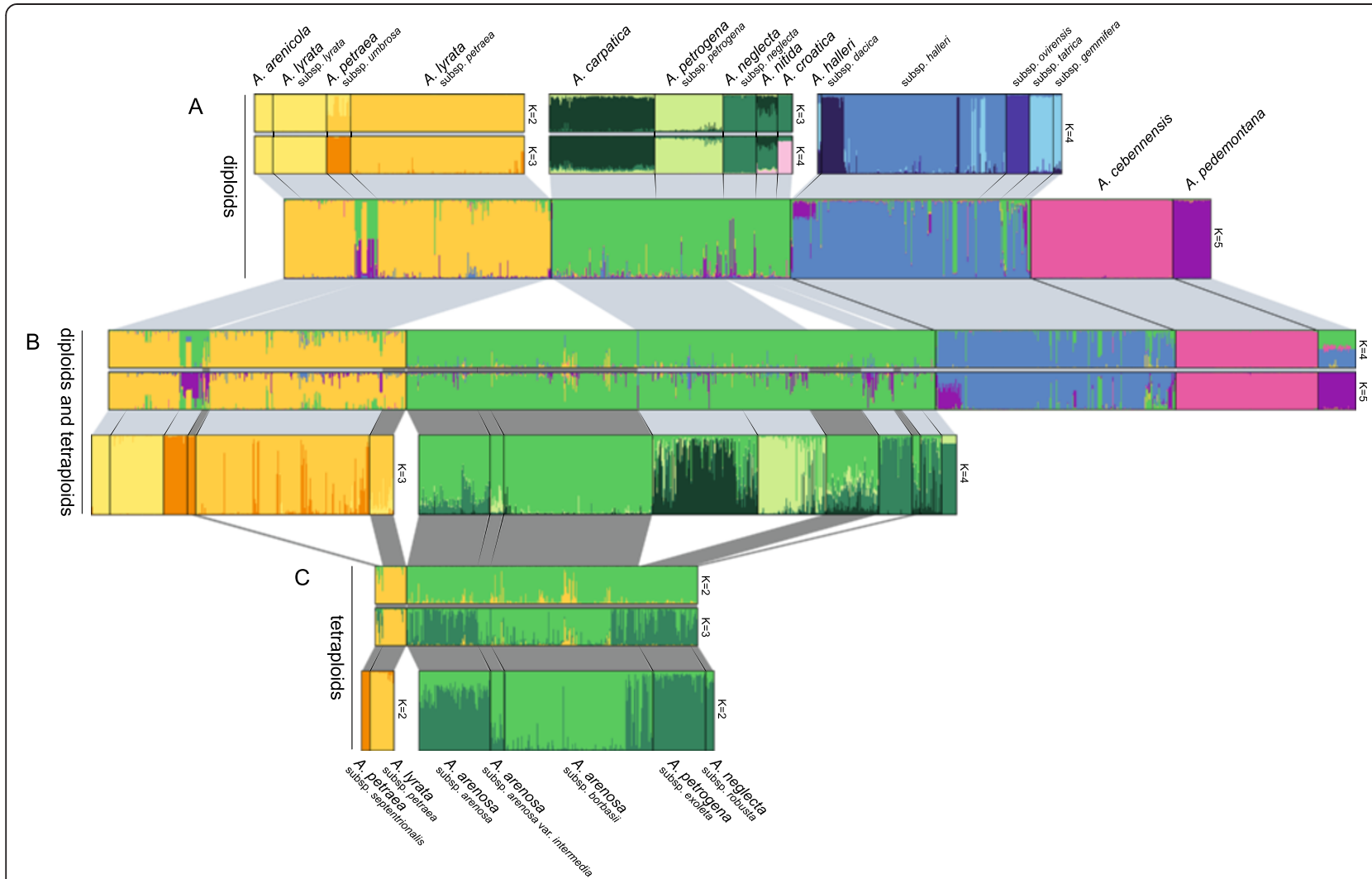

Figure 5 Genetic assignment analysis of microsatellite data in the genus Arabidopsis. Genetic assignment analysis of microsatellite data running STRUCTURE $[82,83]$. A) Total diploid data set separated from the total dataset, B) Total dataset comprising all diploids and tetraploids, C) Tetraploid dataset. For all datasets and analyses (A), (B) and (C) significantly recognized groups have been analyzed further individually (groups separated by white spacers: (A) upper part, (B) lower part, (C) lower part. The A. lyrata group is highlighted in orange and yellow, A. arenosa in green, and $A$. halleri in blue, respectively. The optimal K-values for the various datasets are given with Additional file 4. The total dataset (B) upper part has been divided into an analysis with $K=4$ and $K=5$.

the tetraploid $A$. arenosa group was structured much less clearly $(K=2)$. At best, two groups could be identified: a) mountainous $A$. arenosa subsp. borbasii and highalpine $A$. arenosa var. intermedia, and b) remaining $A$. arenosa subsp. arenosa, $A$. petrogena subsp. exoleta and $A$. neglecta subsp. robusta. It should be noted that neither ITS data nor plastid DNA data differentiated these groups further.

\section{Genetic diversity is similar in all major groups}

Gene diversity and nucleotide diversity is similar among the various groups of taxa (Table 4). Microsatellite gene diversity is highest in A. lyrata and A. arenosa and significantly lower in A. halleri. But this pattern is reverted when considering plastid DNA, where $A$. arenosa shows significantly lower diversity values compared to the $A$. lyrata and $A$. halleri groups. ITS diversity values could be summarized in that $A$. lyrata comprises the most diverse group. Thus, there is some coincidence with wide distribution ranges (A. lyrata and A. halleri) and high overall genetic variation. However, considering that the
A. arenosa group has a much smaller total distribution range compared to the others, it is remarkable that levels of genetic diversity are also high. For the two local endemics, A. cebennensis and A. pedemontana, genetic diversity values are consistently lower.

Mating system affects genetic diversity in the various species and populations. However, detailed information on sporophytic self-incompatibility and mating system is available for A. lyrata and A. halleri only [50-52]. Both are self-incompatible with few exceptions (e.g. few populations of $A$. lyrata subsp. lyrata). Also for the $A$. arenosa lineage there are only reports of a fully self-incompatibility system [29] and there is only one questionable report of a selfing population, so far [53]. Two of the proven allopolyploids (A. suecica, A. kamchatica, not analyzed herein) are selfcompatible $[24,54]$. For many of the remaining taxa and cytotypes no data were available, and we added our results from many inbreeding experiments at Heidelberg Botanical Garden (2003-2014) to Table 3. Most of these taxa are also self-incompatible, and only for $A$. arenicola was selfcompatibility shown, which is well-reflected in lowest 
number of alleles per locus (Table 3) and gene and nucleotide diversity of any marker system used herein (Table 4). Gene diversity (microsatellites, ITS and cpDNA) and nucleotide diversity (ITS and cpDNA) are for both $A$. arenicola and $A$. lyrata subsp. lyrata significantly lower than the respective mean values of the whole lyrata group (t-test: $P<0.01)$. The self-incompatible mating system demonstrated for A. cebennensis in our cultivation experiments might not fit with its low values of number of alleles per locus (Table 3 ) or gene diversity (Table 4). However, these low numbers might be also explained simply by its narrow endemic distribution and small population sizes.

\section{Polyploidy characterizes species groups differently}

Mapping of polyploidy levels across the different taxa in our sample reveals that some lineages consist of diploids only (A. halleri, A. cebennensis, A. pedemontana, Table 1). The origins of tetraploid lineages are less clear e.g. tetraploid $A$. lyrata occurs at low frequency in Great Britain and Austria and there is evidence of introgression from tetraploid close relatives such as $A$. arenosa [29]. Distinguishing between a simple doubling of diploid $A$. lyrata genomes within a single ancestral population (autopolyploidy), or the establishment of polyploid lineages as a result of hybridization and genome doubling between two divergent species (A. lyrata/A. arenosa, allopolyploidy) requires further investigation in this system.

For others such as tetraploid A. septentrionalis, no evidence has been presented for a hybrid origin. The most diverse group of taxa with respect to ploidy variation is the tetraploid and diploid lineages within $A$. arenosa. Of the ten listed taxonomic units within $A$. arenosa, five are tetraploids (Table 1 and Additional file 5). As a source of raw material for natural selection to shape novel genes, this genome duplication may well have contributed to genomic instability, leading to genome rearrangement and a driver of speciation in this group.

Only for the very rare $A$. umezawana (from the $A$. halleri lineage) is no chromosome data available, and unfortunately no leaf material was available for microsatellite analysis. Since sequence data (ITS and chloroplast DNA) do not favor any hybrid origin and the various $A$. halleri segregates are exclusively diploid, A. umezawana probably also represents a diploid taxon. For A. croatica there are diploid and tetraploid chromosome number reports, but the few reports of tetraploids in the field [53] suggest misidentifications as for $A$. arenosa (given the geographic origins of the samples).

\section{Discussion}

We have provided some historical evolutionary context for many of the non-model lineages that comprise the Arabidopsis genus. ITS data provided the most robust signature to separate the main evolutionary lineages (Figures 2 and 5): 1) Arabidopsis thaliana, 2) A. cebennensis, 3) A. pedemontana, 4) A. lyrata and its segregates/ subspecies, 5) $A$. arenosa with numerous different species and cytotypes and $A$. croatica more distinct from the remainder, and 6) A. halleri and its subspecies. This summary excludes two hybrid species, namely Arabidopsis suecica and A. kamchatica "bridging" A. thaliana/A. arenosa and $A$. halleri/A. lyrata, respectively. These taxa will be discussed subsequently, since there is increasing evidence of substantial gene flow over various species and/or ploidy levels $[29,48]$.

\section{Taxonomy and systematics of Arabidopsis halleri and its relatives}

Delimitation of Arabidopsis halleri is still debated among taxonomists. Up to five subspecies have been recognized $[8,9,15,18]$ though two of these, $A$. halleri subsp. gemmifera (Matsum.) O'Kane \& Al-Shehbaz and A. halleri subsp. ovirensis (Wulfen) O'Kane \& Al-Shehbaz, are accepted by some authors as separate species, A. gemmifera (Matsum.) Kadota and A. ovirensis (Wulfen) A. P. Iljinsk., respectively $[11,16]$.

To date, three predominantly central European subspecies were recognized [15]: subsp. halleri, subsp. tatrica (Pawł.) Kolník, and subsp. dacica (Heuff.) Kolník. The third, Asian A. halleri subsp. gemmifera is geographically separated from the other two subspecies [18]. We did not detect these three subspecies here. A. halleri subsp. gemmifera formed a cluster with $A$. halleri subsp. tatrica. Arabidopsis halleri subsp. ovirensis was originally described as endemic to the eastern Austrian high mountain range at Mount Hochobir (Carinthia). Reports from other localities are most likely based on misidentifications (e.g. from Romania and Ukraine). Unique sequence types (ITS and cpDNA) in the populations from Mount Hochobir are in agreement with this narrow endemic distribution [18,22]. Based on microsatellite data, A. halleri subsp. halleri is characterized by different distinct genetic clusters, which is in congruence with the multiple $A$. halleri gene pools shown earlier [31]: here there were two gene pools with admixture between them, and Arabidopsis halleri subsp. dacica did not form a separate genetic cluster. Limited taxon sampling prohibits further interpretation. Although subsp. tatrica did not show genetic distinctiveness in this study, there is "genetic evidence" for the subspecies A. halleri subsp. tatrica [31]. Based on the data presented here, we suggest recognizing five subspecies within A. halleri: gemmifera, tatrica, halleri, ovirensis, and dacica, of which $A$. halleri subsp. ovirensis is a genetically distinct local endemic taxon and of which A. halleri subsp. tatrica and subsp. dacica need further and detailed phylogeographic analysis. We had limited access to material 
from A. umezawana, but based on trnLF and ITS data it is closest to the various subspecies of $A$. halleri.

The evolutionary history of Arabidopsis halleri can be summarized as follows: It has previously been shown that all five subspecies are closely related to each other, and that one major center of genetic diversity is located in the eastern Austrian Alps [18,22,31]. The latter [31] explained this center of genetic diversity by secondary contact and admixture of different European gene pools. Similar to the heavy-metal hyper accumulator $N$. caerulescens [55], it was concluded that $A$. halleri metallicolous populations were founded independently from non-metallicolous populations without suffering from founder effects [30]. We think that radiation within $A$. halleri is likely to have occurred during Pleistocene glaciation and deglaciation cycles [22], which also fits with estimates [56] suggesting it to be $335,000[272,800-438,200]$ years ago for subsp. halleri. Note that this study lacks other subspecies, so a deeper evolutionary split is possible. Furthermore, microsatellite data suggest that $A$. halleri subsp. gemmifera may have originated from $A$. halleri subsp. tatrica from the Tatra Mountains.

\section{Systematics of Arabidopsis arenosa spp. in relation to resolved gene pools}

A. arenosa represents a diploid-tetraploid species complex composed of mainly biennial and predominantly outcrossing individuals [53]. The species complex has a distribution range covering most of Eastern Europe and is found in colline to high-alpine habitats exhibiting wide ecological amplitude, spanning from coastal sand dunes to highalpine screes. Depending on the author, the A. arenosa complex comprises several taxa at various taxonomic levels The complex has been treated as one species, $A$. arenosa, with two subspecies of partly overlapping distribution ranges in Central Europe [3]: the tetraploid subsp. arenosa, also occurring in northern Europe, growing mainly on siliceous bedrock and sandy soil, and the tetraploid subsp. borbasii, growing predominantly on calcareous bedrock in mountainous regions. Diploid $A$. neglecta was described mainly from the Carpathians and rarely from the Alps, where its occurrence is doubtful, since in the Alps this taxon was referred to as Cardaminopsis arenosa var. intermedia [57]. However, we clearly show that this taxon is closer to tetraploid $A$. arenosa subsp. borbasii. Based on morphological and karyological data, several additional (mainly) diploid Carpathian taxa were proposed at the species and subspecies level, and attributed to the genus Cardaminopsis $[53,58]$. Some of these names were never published, however, and kept as "nomina provisoria" (nom. prov.) [59]. Taxonomic concepts in the A. arenosa species complex are still strongly debated [18], and we have endeavored to provide clarification here. The lack of resolution for the slower mutating ITS and $\operatorname{trn} L F$ regions suggests that (recent) radiation within the Pleistocene is plausible for this species complex (the presence of shared ancestry notwithstanding). Our Structure results distinguish mountainous-alpine tetraploid $A$. arenosa subsp. borbasii and $A$. arenosa subsp. arenosa var. intermedia from the remaining tetraploid taxa. Diploid taxa are resolved into A. neglecta subsp. neglecta, A. carpatica, A. petrogena subsp. petrogena, and Arabidopsis nitida. Diploid A. croatica is also well separated and shows clear affinities with the $A$. arenosa species group as a whole (see below).

The $A$. arenosa species complex exhibits the highest levels of genetic diversity within the genus. Only A. lyrata subsp. petraea has comparative values here. In tetraploid $A$. arenosa subsp. arenosa/subsp. borbasii these levels might be explained by (1) local, periglacial survival, (2) lack of genetic bottlenecks and maintenance of large effective population sizes during postglacial migration into formerly glaciated regions, and (3) gene flow between different taxa and/or ploidy levels [19]. In the cases of $A$. carpatica and $A$. petrogena subsp. exoleta, the high levels might be an indicator for past and ongoing speciation within the $A$. arenosa complex in the Western Carpathians [19].

\section{Taxonomy and systematics of $A$. lyrata and its close relatives}

Worldwide, the phylogeography of $A$. lyrata largely reflects its recent introduction by humans. Three biogeographically defined groups have been recognized: Eurasia, the amphiPacific region, and North America [27]. However, the most widely used taxonomy recognizes only two corresponding subspecies (lyrata and petraea), with a third subspecies representing the allopolyploid A. kamchatica [8]. Additional Eurasian taxa such as $A$. septentrionalis and $A$. umbrosa have been treated synonymously under $A$. lyrata subsp. petraea (A. arenicola was at that time treated as a separate taxon) [3]. Our data clearly shows that the North American taxa $A$. lyrata subsp. lyrata and $A$. arenicola are close relatives, and that the self-compatible $A$. arenicola probably originated postglacially from $A$. lyrata populations [27].

In accordance with the Panarctic Flora taxonomic concept microsatellites recognized two arctic taxa: $A$. petraea subsp. umbrosa and $A$. petraea subsp. septentrionalis (Table 1). Both taxa provide a bridge by connecting the European A. lyrata subsp. petraea with the two North American taxa geographically (and genetically). Remarkably, A. petraea subsp. septentrionalis represents a tetraploid taxon and given the high genetic similarity of subsp. umbrosa with subsp. septentrionalis, the latter is most probably an autotetraploid. 


\section{Local endemics and hybrid taxa}

A. cebennensis, A. pedemontana and A. croatica have distinct highly endemic European distribution ranges (NE Italy, SW France and the Velebit mountains in Croatia, respectively). The species also differ markedly in their ecological preferences and morphology, all of which correlates with the deeper phylogenetic splits inferred among these taxa (Figure 2) and the biogeographic affinity of $A$. pedemontana and $A$. cebennensis to $A$. halleri and of $A$. croatica to A. arenosa and A. lyrata. Arabidopsis pedemontana and $A$. cebennensis share some traits with $A$. halleri, such as extensive clonal growth, preference for higher moisture, longevity and occurrence at high. Additionally, there is also a striking correlation with phenology, with increasing plant height from A. halleri, A. pedemontana towards A. cebennensis (up to $1.50 \mathrm{~m}$ tall), and increased preference of continuously available and cool streaming water in the same sequence of species (Figure 6).

These parallel traits support an evolutionary vicariance scenario in potential refugia west of the main distribution area of $A$. halleri, which itself is distributed along the whole alpine mountain chain. The western and relict occurrence of $A$. pedemontana and A. cebennensis may reflect adaptation to refugia during warming phases, i.e. high-and sub-alpine spring habitats with cool streaming water. Our data did not provide enough power for divergence time estimates, but it seems likely that speciation in A. pedemontana and A. cebennensis occurred during early Pleistocene glaciation and deglaciation cycles.

A. croatica, on the other hand, is morphologically and ecologically much closer to diploid taxa of $A$. lyrata and $A$. arenosa. As such, it could be regarded as a derivative of the ancestral gene pool of these respective diploid species (e.g. A. petraea subsp. lyrata, A. carpatica, A. petrogena) (Figure 2) [19].

We did not consider in detail here hybrid taxa such as A. kamchatica and A. suecica. But it is notable that there is increasing evidence of substantial interspecies and interploidal gene flow [48]. It is accepted that $A$. kamchatica has a multiple polytopic origin [27,28], and there is increasing evidence that $A$. suecica does not result from a single hybridization event [60] but rather, multiple events with genetically distinct parents (Polina Novikova, Magnus Nordborg, personal communication), demonstrated and summarized earlier [18]. The first sightings of diploid $A$. arenosa from the Baltic Sea area is now documented (Filip Kolář, Karol Marhold, personal communication), and future genomic analyses will highlight the relationships with putative parental populations of $A$. arenosa and $A$. thaliana. As noted here, $A$. petraea subsp. septentrionalis is very likely of hybrid origin, consistent with botanical notes - with limited sampling and one Russian population only - which concluded “... (this population) may have originated from a different refugium probably located more in the East" [36]. Genomic

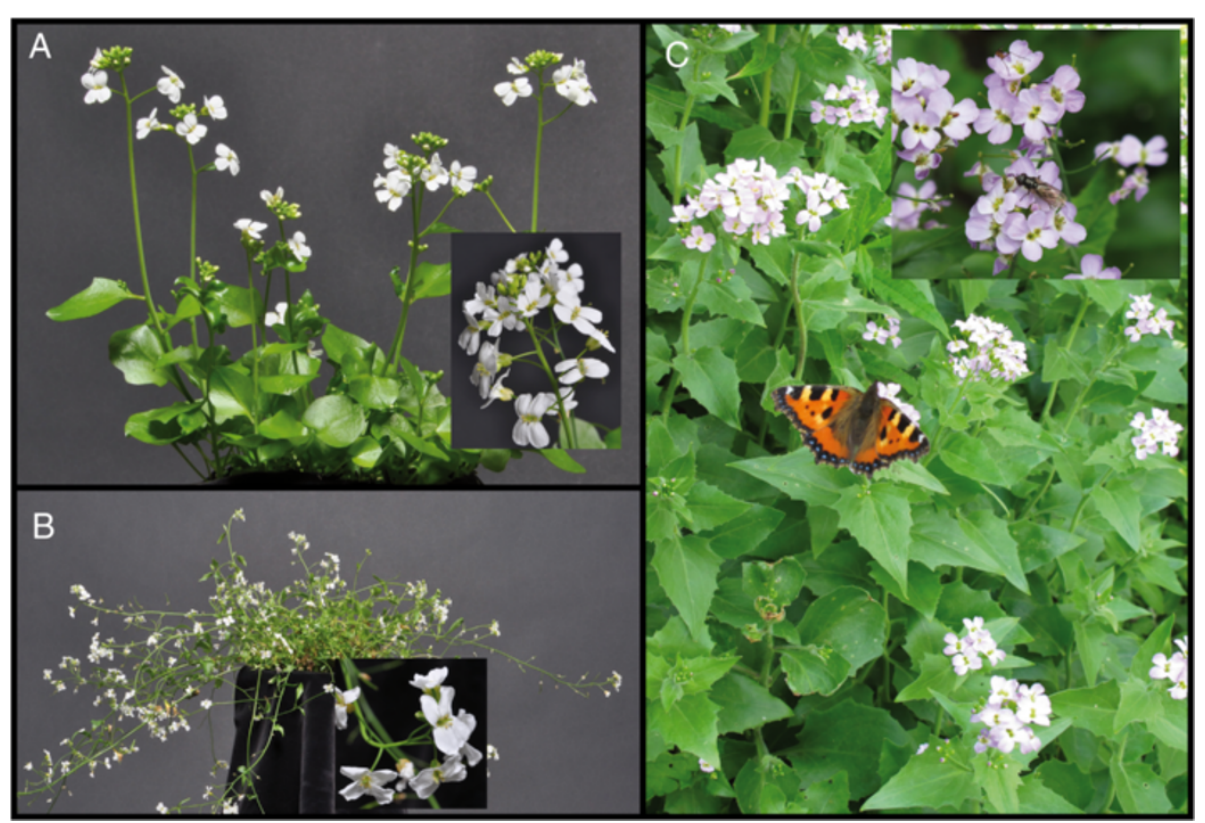

Figure 6 Growth form of various Arabidopsis species. Growth form of selected Arabidopsis species. A) Arabidopsis pedemontana, B) Arabidopsis halleri, C) Arabidopsis cebennensis (photographs taken by MA Koch (๑), U Wagenfeld; Heidelberg). 
analyses of these endemic and hybrid systems will provide further insight into their evolutionary dynamics.

\section{Genome size variation in Arabidopsis}

We did not focus in detail on A. thaliana, but as we saw in this study published estimates of nuclear DNA content size in A. thaliana also show some genomic variation among wild accessions (1.1 fold difference with a mean $1 C$ value of $0.215 \mathrm{pg}$ ) [61]. Absolute values in pg are discussed critically in the same work, and differ largely from other estimates [62,63]. Published results from larger-scale studies were obtained by comparing $A$. halleri and $A$. lyrata while focusing on allopolyploid $A$. kamchatica [64], plants from the latter had a slightly smaller genome size than the sum of its diploid parents. The same study could differentiate genome sizes at the subspecies level, by comparing A. kamchatica subsp. kamchatica and subsp. kawasakiana (larger genome). Data from A. kamchatica [64] showed only small differences compared to data from much smaller sample sizes [65] and focusing on A. lyrata. Another large-scale study [66] focused on European A. lyrata and A. arenosa and demonstrated slightly but significantly larger nuclear DNA content in A. lyrata compared to A. arenosa and its segregates (with both ploidy levels). However, in general there is only a limited number of genome size studies within the genus Arabidopsis. Published genome size with the smallest genome size found in A. arenosa ( $1 \mathrm{Cx}$ of $0.2 \mathrm{pg}$ ) and the largest genome size observed in $A$. cebennensis (1Cx of $0.29 \mathrm{pg}$ ) confirm our results [63].

Some discrepancies are apparent among published studies when comparing absolute values of genome sizes either given in pg or in Mbp but this is mostly due to deviations in methodology (e.g. different standards, different fluorescent dyes, sample preparation, diurnal variation within a sample) [64].

\section{Taxonomic remarks}

We do not formally propose new taxonomical combinations but rather highlight some changes (below) which need to be implemented pending completion of more detailed morphological and phylogeographic analyses.

\section{Arabidopsis arenosa subsp. arenosa var. intermedia}

This taxon is best kept as subsp. of A. arenosa, namely $A$. arenosa subsp. intermedia. This reflects at best that all tetraploid segregates of the $A$. arenosa group closely belong to each other, but also considers the morphological distinctiveness and local alpine occurrence of $A$. arenosa subsp. intermedia.

\section{Arabidopsis umezawana}

We have no evidence of a hybrid origin (e.g. close affinities to hybrid $A$. kamchatica), but instead convincing evidence that it falls into the $A$. halleri group. Consequently the taxon is at best treated as a subspecies, namely A. halleri subsp. umezawana.

\section{Arabidopsis arenicola}

This taxon is closest related to North American A. lyrata subsp. lyrata. Consequently, it should be treated as subspecies under a North American A. lyrata, namely $A$. lyrata subsp. arenicola. Morphological differences are weak: Compared to A. lyrata subsp. lyrata fruits are terete or only slightly flattened, and cotyledons are incumbent [67].

\section{A. lyrata subsp. petraea}

Arabidopsis petraea subsp. septentrionalis and A. petraea subsp. umbrosa have already been described and characterized within the Pan Arctic flora project as subspecies within $A$. petraea. There are two different options to solve this taxonomic/phylogenetic incongruence. 1) European A. lyrata subsp. petraea is treated as $A$. petraea subsp. petraea, thereby taking geographical and genetic affinities into account and not changing taxonomy of subsp. septentrionalis and umbrosa. 2) Treating members of the A. lyrata group on subspecies level and establishing the new combinations $A$. lyrata subsp. septentrionalis and $A$. lyrata subsp. umbrosa. We prefer the second option, since this would minimize future confusion and misuse of species names [21]. Clearly more and detailed studies of these two taxa are needed. From the herein presented microsatellite analysis it could be hypothesized that the $A$. halleri genome is also introgressed into both species. The Structure analysis shows some affinities with the purple genetic cluster and linking in particular subsp. septentrionalis and umbrosa with some populations of $A$. halleri and $A$. pedemontana (Figure 5B, upper part; Figure 5A, lower part), but see comments given above with $A$. pedemontana.

\section{Conclusion}

We characterized in detail the three main Arabidopsis evolutionary lineages: A. halleri, A. lyrata and A. arenosa, including their respective subspecies in an attempt to present a genus-wide overview on genetic variation and taxon delimitation. The relationship among these three lineages is not completely certain due to the power of resolution across the assays used here, but there is some tendency that the lyrata lineage is more closely related to arenosa than to halleri, consistent with being sister taxa. Three additional well-defined endemic species, $A$. pedemontana, A. cebennensis and A. croatica do form separate evolutionary lineages, with the latter (croatica) most likely positioned at the base of the A. arenosa lineage. The other two endemics are distantly related to any other lineage, but ecologically and morphologically closer to A. halleri. Aside from these evolutionary lineages, there is a need to 
characterize some taxa in much more detail, such as the arctic taxa of $A$. lyrata and members of the A. arenosa species aggregate. One other conclusion which stems from the extensive chloroplast haplotype sharing observed among all major evolutionary lineages is the need to qualify and quantify the extent of gene flow within the entire genus.

\section{Methods}

\section{Plant material and general sampling strategy}

This study was designed to incorporate as much existing data as possible in order to provide a comprehensive perspective on taxon sampling as well as their geographic (spatial) distribution. The internal transcribed spacers (ITS1 and ITS2) separating the small and large rRNA subunits and the plastid trnL intron including the adjacent trnL-F intergenic spacer (hereafter called trnLF region). A single individual of respective accessions rather than population-based sampling is common however from these earlier publications. Consequently, many new species accessions and population level sampling have now been added to the existing sample pool. All new individuals have been genotyped using microsatellites using methods established and optimized for the characterization of an Arabidopsis hybrid zone [29].

The different sampling levels (populations versus individual accessions) is also the main reason why ITS and trnLF data are visualized as trees and/or networks (phylogenetics), and microsatellite data were subject to population based algorithms. World-wide sampling localities are provided in Additional file 5 (including GenBank accession numbers) and illustrated in Figure 1. In brief, we sampled 2909 individuals from 813 populations/accessions representing all taxa and cytotypes of the genus Arabidopsis (see also Table 1). For individual marker sets the sampling is as follows: ITS, 1120 individuals/524 accessions; trnLF, 1777 individuals/632 accessions; microsatellites, 1345 individuals/222 accessions; and cytogenetic analysis, 221 accessions. Note that not all sample material was of sufficient quantity or quality for PCR (material included: voucher, wild, living collections). Information on ploidy level (Table 1) is either based on chromosome counts, genome size measurements or indirectly by the numbers of alleles per locus (based on microsatellite genotyping) (see $[19,29]$ for cytological methods). Unambiguous detection of polyploids using microsatellite genotyping is, of course, only possible if more than two alleles are present at a given locus.

\section{DNA isolation, amplification, and sequencing}

Total DNA was obtained from dried leaf material and extracted according to a CTAB protocol [68] with the following modifications: 50-75 mg of dry leaf tissue were ground in $2 \mathrm{ml}$ tubes using a Retsch swing mill
(MM 200), 2 units of RNase A per extraction were added to the isolation buffer, and the DNA pellets were washed twice with $70 \%$ ethanol. DNA was dissolved in $50 \mu \mathrm{l}$ TE-buffer for storage and diluted 1:3 in TE-buffer before use.

For the cpDNA markers $t r n L$ intron and $\operatorname{trn} L / F$ intergenic spacer (trnL/F-IGS), primers and PCR cycling scheme followed the protocol of $[27,69]$, using a PTC200 (MJ Research, Waltham, USA) thermal cycler. The PCR reaction volume of $50 \mu \mathrm{l}$ contained $1 \mathrm{x}$ PCR buffer (10 mM TRIS/50 mM KCl buffer, $\mathrm{pH} 8.0$ ), $3 \mathrm{mM} \mathrm{MgCl}_{2}$, $0.4 \mu \mathrm{M}$ of each primer, $0.2 \mathrm{mM}$ of each dNTP, $1 \mathrm{U}$ Taq DNA polymerase (Amersham Biosciences, Chalfont St Giles, England), and approximately $5 \mathrm{ng}$ of template DNA. Amplified sequences of $t r n L / F-I G S$ included the complete trnL/F-IGS and the first 18 bases of the trnF gene. Amplification of the ITS region was performed according to [70]. PCR reaction conditions were the same as for the two cpDNA markers described above, and PCR cycling scheme was $5 \mathrm{~min}$ at $95^{\circ} \mathrm{C}, 35$ cycles of $1 \mathrm{~min}$ at $95^{\circ} \mathrm{C}$, $1 \mathrm{~min}$ at $48^{\circ} \mathrm{C}$, and $1 \mathrm{~min}$ at $72^{\circ} \mathrm{C}, 10 \mathrm{~min}$ extension at $72^{\circ} \mathrm{C}$, and a final hold at $4^{\circ} \mathrm{C}$. PCR products spanned the entire ITS1, 5.8S, and ITS2 region.

Before sequencing PCR products were checked for length and concentrations on 1.5\% agarose gels and purified with the NucleoFast Kit (Macherey-Nagel, Düren, Germany). The sequencing was performed by GATC GmbH (Konstanz, Germany) and Eurofins MWG Operon (Ebersberg, Germany). Additionally, cycle-sequencing was performed on the MegaBase500 system using the DYEnamic ET Terminator Cycle Sequencing Kit (Amersham Biosciences, Chalfont St Giles, England).

\section{Microsatellite amplification and allele detection}

Microsatellites were chosen from previous studies of $A$. lyrata $[29,71]$. The allopolyploid $A$. kamchatica, $A$. suecica and introgressed tetraploid hybrids of A. lyrata subsp. petraea and $A$. arenosa were excluded from this analysis. Selection criteria, PCR and genotyping conditions are provided in detail together with a list of the seven SSRs finally chosen for the analyses in our previous contribution [29]. Scoring of fragment sizes and fluorescence intensity/peak heights (in tetraploids) was automatically performed with GeneMarker version 1.95 (SoftGenetics, State College PH, USA) using respective panels for each locus with subsequent manual checking of each sample. Allele frequencies within tetraploid individuals could unambiguously be assigned manually for the majority of individuals, based on the fluorescence intensity of the fragment peaks [29].

\section{Estimation of nuclear DNA content}

Nuclear DNA content was determined using flow cytometry following a simplified two-step protocol [72]. 
Approximately $10 \mathrm{~mm}^{2}$ of fresh leaf tissue (or one fresh petal) from each plant was chopped together with an appropriate volume of the internal reference standard (Solanum pseudocapsicum, 2C $=2.59$ pg, [73]; an identical individual was used for all measurements) using a razor blade in a Petri-dish containing $0.5 \mathrm{~mL}$ of icecold Otto I buffer (0.1 M citric acid, 0.5\% Tween 20). The suspension was filtered through a $42-\mu \mathrm{m}$ nylon mesh and incubated for $10 \mathrm{~min}$ at room temperature. Isolated nuclei were stained with $1 \mathrm{~mL}$ of Otto II buffer (0.4 $\left.\mathrm{M} \mathrm{Na}_{2} \mathrm{HPO}_{4} \cdot 12 \mathrm{H}_{2} \mathrm{O}\right)$ supplemented with propidium iodide and RNase (both in concentration $50 \mu \mathrm{g} \mathrm{mL}^{-1}$ ), and $\beta$-mercaptoethanol in concentration $2 \mu \mathrm{g} \mathrm{mL} \mathrm{m}^{-1}$. After a few minutes, the relative fluorescence intensity of 5000 particles was recorded using flow cytometer CyFlow SL (Partec GmbH, Germany) equipped with green (532 nm) solid state laser. We applied the following stringent criteria in order to get precise and stable flow cytometric results: (i) only analyses with the coefficient of variation of the sample peak below 3\% were taken into account (ii) each sample was measured at least three times on different days to minimize potential random instrumental drift [74], and (iii) the between-day variation was defined to not exceed the 3\% threshold; otherwise the most remote value was discarded and the sample was re-analyzed. The histograms were evaluated with FloMax FCS 2.0 program (Partec GmbH, Germany). Differences in homoploid nuclear DNA contents among major gene pools (separately for diploid and tetraploid accessions) were analyzed by one-way ANOVA with TukeyHSD post-hoc comparisons in $\mathrm{R}$ v.2.15.2 [75]. The dataset comparing relative genome sizes of taxonomic groups was generated in Prague. A second dataset was generated in Heidelberg to provide some estimates on absolute genome sizes. The second dataset incorporated different standards (Solanum lycopersicum cv. Stupicke, 0.98 pg/1C; and Raphanus sativus cv. Saxa, $0.55 \mathrm{pg} / 1 \mathrm{C}$ ) [76] because of comparing to, and integrating into datasets from all over the Brassicaceae. Respective data are deposited in BrassiBase [20,77]. The two datasets were not merged afterwards and kept separate, because accessions analyzed and standards used were different (as explained above).

\section{ITS and trnLF DNA sequence delimitation}

Plastidic trnLF sequences were defined as haplotypes and suprahaplotypes following previous studies [18,22,26,29]: Haplotypes are characterized by multiple trnF pseudogenes in the 3 '-region of the trnLF-IGS close to the functional trnF gene $[26,78,79]$. When defining respective trnLF suprahaplotypes, we excluded the pseudogene-rich region and thereby merged sets of haplotypes into suprahaplotypes. The trnF pseudogenes evolve with a mutation rate $10 \times$ higher than single nucleotide polymorphisms, which makes them non-applicable for phylogenetic reconstruction at the species level $[26,80,81]$. In summary, haplotypes belonging to one suprahaplotype share the same base order throughout the whole sequence except for the pseudogene-rich region, where they vary in both length and base content. Suprahaplotypes differ from each other only by single point mutations and/or indels. Newly defined trnLF haplotypes were assigned to GenBank [LN610052-LN610063/LN610032-LN610051)] (Additional files 3 and 5). ITS sequences were obtained from direct sequencing of PCR products and defined as previously [18,22,26,29]. A few minor corrections of past ITS type numbering had to be conducted, and codes are indicated in Additional file 5 with new assignments to GenBank [LN610064-610098].

\section{Network, phylogenetic analysis and genetic diversity statistics}

Network analyses and genetic diversity statistics were exclusively performed using the trnLF suprahaplotypes, as the pseudogene-rich region is not applicable for phylogenetic reconstruction at the species level [26]. The alignment of the cpDNA sequences was manually made with subsequent adjustment in PhyDE version 0.9971 [82]. The network was constructed using TCS version 1.21 [83] and the statistical parsimony algorithm [84]. Gaps (except polyT stretches) were coded as single additional binary characters. Reliability of certain connections, especially if multiple and internal connections occurred within the network, was tested by analyzing the respective alignment with maximum likelihood-based tree construction methods [85]. Only those connections showing up in both types of analyses were retained. Any unsupported connections are indicated with dashed lines in the respective figure. DNA sequence information from $A$. thaliana was used to set the root.

ITS sequences were also aligned manually with subsequent adjustment in PhyDE version 0.9971 [82]. Maximum parsimony analysis was performed running PAUP 4.0b10 [86] and using $A$. thaliana as an outgroup. The parsimony heuristic search was performed with the following settings: gaps were treated as missing data (using the gap-based coded 0/1-matrix), multi-state taxa were interpreted as uncertainty; tree construction was via stepwise addition; tree-bisection-reconnection (TBR) was implemented via the branch-swapping algorithm; MaxTrees limit was set to 10,000; and the MulTrees option was selected (saving all minimal trees found during branch swapping). For bootstrapping, 1000 replicates with a tree maximum of 500 retained trees were run. The resulting phylogenetic hypothesis was used to manually place the root in a reliable way with the subsequently performed network analysis (SplitsTree 4.13.1; [87]). For the network analysis $A$. thaliana was removed from the dataset to 
increase resolution of internal splits (removing homoplastic characters).

Genetic diversity statistics were performed with Arlequin version 3.5.1.3 [88] and Nei's genetic diversity and gene diversity was calculated accordingly [89]. Allopolyploids (Arabidopsis kamchatica, A. suecica, introgressed A. lyrata subsp. petraea) and individuals which could only be assigned to a lineage but not to lower taxonomic units were excluded from the analyses.

\section{Genotyping of microsatellite alleles and genetic assignment tests}

We obtained comparatively full datasets for diploid and tetraploid microsatellite allele scoring (Additional file 6). Microsatellite genotypes were analyzed using Structure 2.3.4 [90,91], with ten replicate runs for each $K$-value, and a burn-in period of $1 \times 10^{5}$ and $2 \times 10^{5}$ iterations. The options 'admixture model' was used in combination with 'uncorrelated allele frequencies'. The estimation of the optimal $K$ number of populations (ranging from 1 to 10 ) was calculated using the R-script Structure-sum [92], which compares the posterior probabilities of the runs [93], the similarity coefficient between the runs, and delta $K$ as defined by [94]. In the visualization of Evanno's delta $K$, a peak had to appear in the optimal fitting model with consistent results over multiple runs [92,94]. Input files for CLUMPP were generated with STRUCTURE HARVESTER [95], alignments of replicate runs were conducted in CLUMPP [96] and the mean of 10 runs was visualized [97]. Note that for some of the more complicated groupings (e.g. diploids with all species accessions) the variance between independent runs for $K$ with the highest delta $K$ (optimal $K$ according to the method of Evanno [94]) was high. In these cases we turned to the variance for guidance concerning the correct $K$, and choose $K$ with the lowest variability across runs. At all times we aimed for the smallest value of $K$ that captured most of the structure in the data with a clear biological interpretation for individual assignments.

To overcome conceptual restrictions in combining diploid and tetraploid data we conducted three separate analyses: I) on the whole ploidy dataset, this combined diploids and tetraploids where diploid alleles were doubled to mimic tetraploid data; II) diploids only; and III) tetraploids only. Following these three analyses Structure was again run on the subsets of accessions detected by analysis I to III.) The whole dataset (I) comprised 24 taxa and 1345 individuals and was subsequently split into two separate runs. The diploid dataset (II) comprised 17 taxa and 998 individuals and was subsequently split into three separate runs. The tetraploid dataset (III) comprised seven taxa and 347 individuals and was subsequently split into two separate runs. For those subsets we also tested for optimal $K$-values. LocPriors were set with split datasets to optimize search strategies using taxon labels. Two aspects have to be considered regarding the Structure analyses: 1) We excluded a priori any known hybrid taxon from the analyses (e.g. A. suecica, A. kamchatica, A. lyrata from the eastern Austrian Forealps and the Wachau in Austria; for details see: [27,29,48], and 2) almost all taxa are obligate outcrossers (known self-compatible exceptions are the few populations of A. lyrata in the Great Lakes region of eastern North America: [33,51]; A. kamchatica and A. kamchatica subsp. kawasakiana from Japan: [54,98]; A. suecica [99]; A. arenicola, this study). It can also be assumed that $A$. kamchatica is self-compatible. Genetic diversity statistics were performed with Arlequin 3.5.1.3 [88] for diploid taxa.

\section{Availability of supporting data}

The data sets supporting the results of this article are available online. A complete documentation of the new sequences generated for this study, including GenBank accession numbers, is available from Additional file 5 . Further, data files (accession list; ITS alignment; microsatellite dataset) are accessible with the Dryad data repository under doi:10.5061/dryad.497sg.

\section{Additional files}

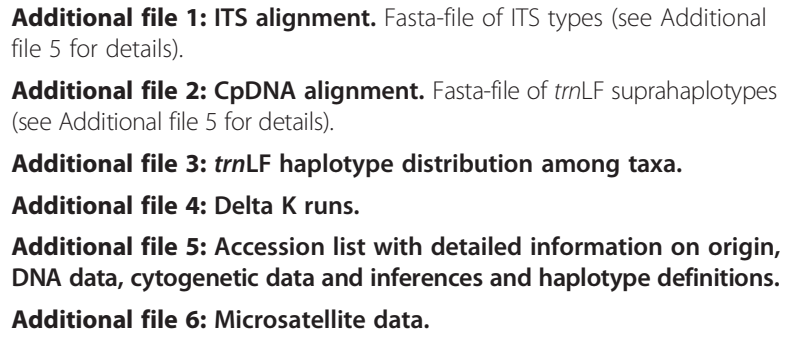

Additional file 2: CpDNA alignment. Fasta-file of trnLF suprahaplotypes (see Additional file 5 for details).

Additional file 3: trnLF haplotype distribution among taxa.

Additional file 4: Delta $\mathrm{K}$ runs.

Additional file 5: Accession list with detailed information on origin, DNA data, cytogenetic data and inferences and haplotype definitions. Additional file 6: Microsatellite data.

Competing interests

The authors declare that they have no competing interests.

\section{Authors' contributions}

$\mathrm{NH}$ and RS carried out the molecular marker studies and statistical analyses, and contributed to drafting the manuscript. ML and FK conducted part of genome size measurements and contributed to drafting the manuscript. TJC and KM helped with plant material and contributed to drafting the manuscript. MAK designed and coordinated the project, analyzed and integrated the results and drafted the manuscript. All authors read and approved the final version. With the exception of part of the genome size analysis, most of the work was done in Heidelberg.

\section{Acknowledgments}

We thank Ihsan Al-Shehbaz (Missouri, USA), Galina Gusarova (Oslo, Norway), Gu Hongya (Beijing, P. R. China), Barbara Mable (Glasgow, Scotland), David L. Remington (Greensboro, USA), Outi Savolainen (Oulu, Finland) and the curators of the Herbariums of the Natural History Museums London and Vienna for providing plant material, Susanne Ball, Liza Kretz and Peter Sack for laboratory assistance. We are very grateful to Graham Muir for countless valuable comments and careful editing of the manuscript. This research was supported by DFG grants KO 2302/5 and KO 2302/14 (priority research program DFG-SPP 1529) to Marcus A. Koch and by the Czech Science Foundation grant no. P506/12/0668 to Karol Marhold. 


\section{Author details}

${ }^{1}$ Centre for Organismal Studies (COS) Heidelberg, Heidelberg University, Heidelberg 69120, Germany. ${ }^{2}$ Institute of Botany, Academy of Sciences of the Czech Republic, Průhonice CZ-25243, Czech Republic. ${ }^{3}$ Department of Life Sciences, Cheng-Kung University, Tainan, Taiwan. ${ }^{4}$ Department of Botany, Faculty of Science, Charles University in Prague, Benátská 2, Prague CZ-128 01, Czech Republic. ${ }^{5}$ Institute of Botany Slovak Academy of Sciences, Dúbravská cesta 9, Bratislava SK-845 23, Slovakia.

\section{Received: 27 June 2014 Accepted: 15 October 2014}

Published online: 27 October 2014

\section{References}

1. Clauss M, Koch MA: Arabidopsis and its poorly known relatives. Trends PI Sci 2006, 11:449-459.

2. Al-Shehbaz IA, O'Kane SL, Price RA: Generic placement of species excluded from Arabidopsis. Novon 1999, 9:296-307.

3. Al-Shehbaz IA, O'Kane SL: Taxonomy and phylogeny of Arabidopsis (Brassicaceae). In The Arabidopsis Book 2002, Volume 1. Edited by Torii K The American Society of Plant Biologists; 2002:e0001. doi:10.1199/tab.0001.

4. Koch M, Bishop J, Mitchell-Olds T: Molecular systematics and evolution of Arabidopsis and Arabis. Pl Biol 1999, 1:529-537.

5. Koch MA, Haubold B, Mitchell-Olds T: Comparative evolutionary analysis of chalcone synthase and alcohol dehydrogenase loci in Arabidopsis, Arabis, and related genera (Brassicaceae). Mol Biol Evol 2000, 17:1483-1498.

6. Koch MA, Haubold B, Mitchell-Olds T: Molecular systematics of the Brassicaceae: evidence from coding plastidic MATK and nuclear CHS sequences. Am J Bot 2001, 88:534-544

7. Karl R, Koch MA: A world-wide perspective on crucifer speciation and evolution: phylogeny, biogeography and trait evolution in tribe Arabideae. Ann Bot 2013, 112:983-1001.

8. O'Kane SL, Al-Shehbaz IA: A synopsis of Arabidopsis (Brassicaceae). Novon 1997, 7:323-327

9. O'Kane SL, Al-Shehbaz IA: Phylogenetic position and generic limits of Arabidopsis (Brassicaceae) based on sequences of nuclear ribosomal DNA. Ann Missouri Bot Gard 2003, 90:603-612.

10. Warwick SI, Al-Shehbaz IA, Sauder CA: Phylogenetic position of Arabis arenicola and generic limits of Aphragmus and Eutrema (Brassicaceae) based on sequences of nuclear ribosomal DNA. Can J Bot 2006, 84:269-281

11. Kadota Y: Arabidopsis umezawana (Brassicaceae), a new species from Mt. Rishirizan, Rishiri Island, Hokkaido, Northern Japan. J Jpn Bot 2007, 82:232-237.

12. Dorofeyev Vl: Cruciferae of European Russia. Turczaninowia 2002, 5:5-114

13. Marhold K, Perný M, Kolník M: Miscellaneous validations in Cruciferae and Crassulaceae. Willdenowia 2003, 33:69-70.

14. Shimizu KK, Fujii S, Marhold K, Watanabe K, Kudoh H: Arabidopsis kamchatica (Fisch. ex DC.) K. Shimizu \& Kudoh and A. kamchatica subsp. kawasakiana (Makino) K. Shimizu \& Kudoh, new combinations. Acta Phytotax Geobot 2005, 56:163-172.

15. Kolnik M, Marhold K: Distribution, chromosome numbers and nomenclature conspect of Arabidopsis halleri (Brassicaceae) in theCarpathians. Biologia (Bratislava) 2006, 61:41-50.

16. Iljinska A, Didukh Y, Burda R, Korotschenko I: Ecoflora of Ukraine, Volume 5. Kyiv: Phytosociocentre Press; 2007.

17. Elven DR, Murray J: New combinations in the Panarctic vascular plant flora. J Bot Res Inst Texas 2008, 2:433-438.

18. Koch MA, Wernisch M, Schmickl R: Arabidopsis thaliana's wild relatives: an updated overview on systematics, taxonomy and evolution. Taxon 2008 , 57:933-943.

19. Schmickl R, Paule J, Klein J, Marhold K, Koch MA: The evolutionary history of the Arabidopsis arenosa species complex: Highly diverse tetraploids mask that the Western Carpathians are the center of species and genetic diversity. PLoS One 2012, 7:e42691.

20. Koch MA, Kiefer M, German D, Al-Shehbaz IA, Franzke A, Mummenhoff K BrassiBase: tools and biological resources to study characters and traits in the Brassicaceae - version 1.1. TAXON 2012, 61:1001-1009.

21. Koch MA, German D: Taxonomy and systematics are key to biological information: Arabidopsis, Eutrema (Thellungiella), Noccaea and Schrenkiella (Brassicaceae) as examples. Frontiers PI Science 2013, 4:e267.
22. Koch MA, Matschinger M: Evolution and genetic differentiation among relatives of Arabidopsis thaliana. Proc Natl Acad Sci U S A 2007 104:6272-6277.

23. Castric V, Bechsgaard J, Schierup MH, Vekemans X: Repeated adaptive introgression at a gene under multiallelic balancing selection. PLOS Genet 2008, 4:e1000168.

24. Säll T, Jakobsson M, Lind-Halldén C, Halldén C: Chloroplast DNA indicates a single origin of the allotetraploid Arabidopsis suecica. J Evol Biol 2003, 16:1019-1029

25. Jakobsson M, Hagenblad J, Tavaré S, Säll T, Halldén C, Lind-Halldén C, Nordborg M: A unique recent origin of the allotetraploid species Arabidopsis suecica: evidence from nuclear DNA markers. Mol Biol Evol 2006, 23:1217-1231.

26. Schmickl R, Jørgensen MH, Brysting AK, Koch MA: Phylogeographic implications for the North American boreal-arctic Arabidopsis lyrata complex. Plant Ecol Div 2008, 1:245-254.

27. Schmickl R, Jorgenson M, Brysting A, Koch MA: The evolutionary history of the Arabidopsis lyrata complex: a hybrid in the amphi-Beringian area closes a large distribution gap and builds up a genetic barrier. BMC Evol Biol 2010, 10:e98.

28. Shimizu-Inatsugi R, Lihová J, Iwanaga H, Kudoh H, Marhold K, Savolainen O, Watanabe K, Yakubov W, Shimizu KK: The allopolyploid Arabidopsis kamchatica originated from multiple individuals of Arabidopsis lyrata and Arabidopsis halleri. Mol Ecol 2009, 18:4024-4048.

29. Schmickl R, Koch MA: Arabidopsis hybrid speciation processes. Proc Natl Acad Sci U S A 2011, 108:14192-14197.

30. Pauwels M, Saumitou-Laprade P, Holl AC, Petit D, Bonnin I: Multiple origin of metallicolous populations of the pseudometallophyte Arabidopsis halleri (Brassicaceae) in Central Europe: the cpDNA testimony. Molec Ecol 2005, 14:4403-4414.

31. Pauwels $M$, Vekemans $X$, Godé $C$, Frérot $H$, Castric V, Saimitou-Laprade $P$ : Nuclear and chloroplast DNA phy logeography reveals vicariance among European popula tions of the model species for the study of metal tolerance, Arabidopsis halleri (Brassicaceae). New Phytol 2012, 193:916-928.

32. Tedder A, Hoebe PN, Ansell SK, Mable BK: Using chloroplast genes for phylogeography in Arabidopsis lyrata. Diversity 2010, 2:653-678.

33. Hoebe PN, Stift M, Tedder A, Mable BK: Multiple losses of selfincompatibility in North-American Arabidopsis lyrata? Phylogeographic context and population genetic consequences. Mol Ecol 2009, 18:4294-4939.

34. Clauss M, Mitchell-Olds T: Population genetic structure of Arabidopsis lyrata in Europe. Mol Ecol 2006, 15:2753-2766.

35. Kuittinen $H$, Niittyvuopio A, Rinne $P$, Savolainen O: Natural variation in Arabidopsis lyrata vernalization requirement conferred by a FRIGIDA indel polymorphism. Mol Biol Evol 2008, 25:319-329.

36. Muller MH, Leppälä J, Savolainen O: Genome-wide effects of postglacial colonization in Arabidopsis lyrata. Heredity 2008, 100:47-58.

37. Riihimäki M, Podolsky R, Kuittinen $H$, Koelewijn $H$, Savolainen O: Studying genetics of adaptive variation in model organisms: flowering time variation in Arabidopsis lyrata. Genetica 2005, 123:63-74.

38. Leinonen PH, Sandring S, Quilot B, Clauss MJ, Mitchell-Olds T, Agren J, Savolainen O: Local adaptation in European populations of Arabidopsis Iyrata (Brassicaceae). Am J Bot 2009, 96:1129-1137.

39. Turner TL, Von Wettberg EJ, Nuzhdin SV: Genomic analysis of differentiation between soil types reveals candidate genes for local adaptation in Arabidopsis lyrata. PLoS One 2008, 3:e3183.

40. Savolainen O, Kuittinen H: Arabidopsis lyrata genetics. In Genetics and Genomics of the Brassicaceae. Edited by Bancroft I, Schmidt R. New York: Springer Verlag; 2011:347-372.

41. Comai L, Tyagi AP, Winter K, Holmes-Davis R, Reynolds SH, Stevens $Y$, Byers $B$ : Phenotypic instability and rapid gene silencing in newly formed Arabidopsis allotetraploids. Plant Cell 2000, 12:1551-1568.

42. Madlung A, Tyagi AP, Watson B, Jiang H, Kagochi T, Doerge RW, Martienssen R, Comai L: Genomic changes in synthetic Arabidopsis polyploids. Plant J 2005, 41:221-230.

43. Hollister J, Arnold B, Svedin E, Xue K, Dilkes B, Bomblies K. Genetic adaptation associated with genome-doubling in autotetraploid Arabidopsis arenosa. PLoS Genet 2012, 8:e1003093.

44. Yant L, Hollister JD, Wright KM, Arnold BJ, Higgins JD, Franklin FCH, Bomblies K: Meiotic adaptation to genome duplication in Arabidopsis arenosa. Curr Biol 2013, 23:2151-2156. 
45. Hunter B, Bomblies K: Progress and promise in using Arabidopsis to study adaptation, divergence and speciation. In The Arabidopsis Book 2010, Volume 8. Edited by Torii K. Rockville, MD: American Society of Plant Biologists; 2010:e0138.

46. Hu TT, Pattyn P, Bakker EG, Cao J, Cheng JF, Clark RM, Fahlgren N, Fawcett JA, Grimwood J, Gundlach H, Haberer G, Hollister JD, Ossowski S, Ottilar RP Salamov AA, Schneeberger K, Spannagl M, Wang X, Nasrallah ME, Bergelson J, Carrington JC, Gaut BS, Schmutz J, Mayer KFX, Van de Peer Y, Grigoriev IV, Nordborg M, Weigel D, Guo YL: The Arabidopsis lyrata genome sequence and the basis of rapid genome size change. Nat Genet 2011, 43:476-481.

47. Koch M, Dobes C, Mitchell-Olds T: Multiple hybrid formation in natural populations: concerted evolution of the internal transcribed spacer of nuclear ribosomal DNA (ITS) in North American Arabis divaricarpa (Brassicaceae). Mol Biol Evol 2003, 20:338-350.

48. Jorgensen MH, Ehrich D, Schmickl R, Koch MA, Brysting A: Interspecific and interploidal gene flow in Central European Arabidopsis (Brassicaceae). BMC Evol Biol 2011, 11:e346.

49. Ross-Ibarra J, Wright SI, Foxe JP, Kawabe A, DeRose-Wilson L, Gos G, Charlesworth D, Gaut BS: Patterns of polymorphism and demographic history in natural populations of Arabidopsis lyrata. PLOS One 2008, 3:e2411.

50. Mable BK, Schierup MH, Charlesworth D: Estimating the number, frequency, and dominance of S-alleles in a natural population of Arabidopsis lyrata (Brassicaceae) with sporophytic control of self-incompatibility. Heredity 2003, 90:422-431.

51. Mable BK, Robertson AV, Dart S, DiBerardo C, Witham L: Breakdown of self-incompatibility in the perennial Arabidopsis lyrata (Brassicaceae) and its genetic consequences. Evolution 2005, 59:1437-1448.

52. Roux C, Pauwels M, Ruggiero MV, Charlesworth D, Castric V, Vekemans X: Recent and ancient signature of balancing selection around the S-locus in Arabidopsis halleri and Arabidopsis lyrata. Mol Biol Evol 2013, 30:435-447.

53. Měsíček J: Chromosome counts in Cardaminopsis arenosa agg. (Cruciferae). Preslia 1970, 42:225-248.

54. Tsuchimatsu T, Kaiser P, Yew CL, Bachelier JB, Shimizu KK: Recent loss of self-incompatibility by degradation of the male component in allotetraploid Arabidopsis kamchatica. PLoS Genet 2012, 8:e1002838.

55. Koch M, Mummenhoff K, Hurka H: Systematics and evolutionary history of heavy metal tolerant Thlaspi caerulescens in Western Europe: evidence from genetic studies based on isozyme analysis. Biochem Syst Ecol 1998, 26:823-838.

56. Roux C, Castric V, Pauwels M, Wright SI, Saumitou-Laprade P, Vekemans X: Does speciation between Arabidopsis halleri and Arabidopsis lyrata coincide with major changes in a molecular target of adaptation? PLoS One 2011, 6:e26872.

57. Hayek A: Flora von Steiermark. Berlin: Verlag von Gebrüder Bornträger; 1908-1914

58. Měsiček J: Cardaminopsis. In Zoznam nižších a vyšších rastlín Slovenska Checklist of non-vascular and vascular plants of Slovakia. Edited by Marhold K, Hindák F. Bratislava: VEDA; 1998:395-396.

59. Kolník M: Arabidopsis. In Chromosome number Survey of The Ferns and Flowering Plants of Slovakia. Edited by Marhold K, Mártonfi P, Mereda P Jr, Mráz P. Bratislava: VEDA; 2012:94-102

60. Jakobsson M, Hagenblad J, Tavaré S, Säll T, Halldén C, Lind-Halldén C, Nordborg M: A unique recent origin of the allotetraploid species Arabidopsis suecica: evidence from nuclear DNA markers. Molec Biol Evol 2006, 23:1217-1231.

61. Schmuths H, Meister A, Horres R, Bachmann K: Genome size variation among accessions of Arabidopsis thaliana. Ann Bot 2004, 93:317-321.

62. Johnston SP, Pepper AE, Hall AE, Chen ZF, Hodnett G, Drabek J, Lopez R, Price HJ: Evolution of genome size in Brassicaceae. Ann Bot 2005, 95:229-235.

63. Lysak MA, Koch MA, Leitch IJ, Beaulieau JM, Meister A: The dynamic ups and downs of genome size evolution in Brassicaceae. Mol Biol Evol 2009, 26:85-98.

64. Wolf DE, Steets JA, Houliston GJ, Takebayashi N: Genome size variation and evolution in a allotetraploid Arabidopsis kamchatica and its parents, Arabidopsis lyrata and Arabidopsis halleri. AOB PLANTS 2014, 6: doi:10.1093/ aobpla/plu025.

65. Dart S, Kron P, Mable BK: Characterizing polyploidy in Arabidopsis lyrata using chromosome counts and flow cytometry. Canad J Bot 2004, 82:185-197.
66. Jørgensen MH, Ehrich D, Schmickl R, Koch MA, Brysting AK: Interspecific and interploidal gene flow in central european Arabidopsis (Brassicaceae). BMC Evol Biol 2011, 11:e346.

67. Al-Shebaz IA: Arabidopsis. In Flora of North America, Volume 7. Oxford: Oxford University Press; 2010:447-449.

68. Doyle JJ, Doyle JL: A rapid DNA isolation procedure for small quantities of fresh leaf tissue. Phytochem Bull 1987, 19:11-15.

69. Dobeš $\mathrm{CH}$, Mitchell-Olds T, Koch MA: Extensive chloroplast haplotype variation indicates Pleistocene hybridization and radiation of North American Arabis drummondii, A. x divaricarpa, and A. holboellii (Brassicaceae). Mol Ecol 2004, 13:349-370.

70. Dobes C, Mitchell-Olds T, Koch M: Intraspecific diversification in North American Arabis drummondii, A. ×divaricarpa, and A. holboellii (Brassicaceae) inferred from nuclear and chloroplast molecular markers - an integrative approach. Am J Bot 2004, 91:2087-2101.

71. Clauss MJ, Cobban H, Mitchell-Olds T: Cross-species microsatellite markers for elucidating population genetic structure in Arabidopsis and Arabis (Brassicaeae). Mol Ecol 2002, 11:591-601.

72. Doležel J, Greilhuber J, Suda J: Estimation of nuclear DNA content in plants using flow cytometry. Nat Protoc 2007, 2:2233-2244.

73. Temsch EM, Greilhuber J, Krisai R: Genome size in liverworts. Preslia 2010 82:63-80.

74. Doležel J, Bartoš J: Plant DNA flow cytometry and estimation of nuclear genome size. Ann Bot 2005, 95:99-110.

75. R Development Core Team: R: A language and Environment for Statistical Computing. Vienna, Austria: R Foundation for Statistical Computing; 2013. http://www.R-project.org.

76. Dolezel J, Sgorbati S, Lucretti S: Comparison of three fluorochromes for flow cytometric estimation of nuclear DNA content in plants. Physiol Plantarum 1992, 85:625-631.

77. Kiefer M, Schmickl R, German D, Lysak M, Al-Shehbaz IA, Franzke A, Mummenhoff K, Stamatakis A, Koch MA: BrassiBase: introduction to a novel knowledge database on Brassicaceae evolution. Plant Cell Physiol 2014, 55:e3.

78. Koch MA, Dobeš C, Matschinger M, Bleeker W, Vogel J, Kiefer M, Mitchell-Olds T: Evolution of the trnF(GAA) gene in Arabidopsis relatives and the Brassicaceae family: monophyletic origin and subsequent diversification of a plastidic pseudogene. Mol Biol Evol 2005, 22:1032-1043.

79. Dobeš C, Kiefer C, Kiefer M, Koch MA: Plastidic trnFUUC pseudogenes in North American genus Boechera (Brassicaceae): mechanistic aspects of evolution. Plant Biol 2007, 9:502-515.

80. Koch MA, Dobeš C, Kiefer C, Schmickl R, Klimeš L, Lysak MA: Supernetwork identifies multiple events of plastid $\operatorname{trn} \mathrm{F}(\mathrm{GAA})$ pseudogene evolution in the Brassicaceae. Mol Biol Evol 2007, 24:63-73.

81. Schmickl R, Kiefer C, Dobeš C, Koch MA: Evolution of trnF(GAA) pseudogenes in cruciferous plants. Plant Syst Evol 2008, [doi:10.1007/ s00606-008-0030-2]

82. Müller K, Quandt D, Müller J, Neinhuis C: PhyDE, Version 0.92: Phylogenetic Data Editor; 2005. http://www.phyde.de.

83. Clement M, Posada D, Crandall KA: TCS: a computer program to estimate gene genealogies. Mol Ecol 2000, 9:1657-1659.

84. Templeton AR, Crandall KA, Sing CF: A cladistic analysis of phenotypic associations with haplotypes inferred from restriction endonuclease mapping and DNA sequence data. III. Cladogram estimation. Genetics 1992, 132:619-633.

85. Stamatakis A: RAxML Version 8: A tool for phylogenetic analysis and post-analysis of large phylogenies. Bioinformatics 2014, doi:10.1093/ bioinformatics/btu033.

86. Swofford DL: PAUP*: Phylogenetic Analysis Using Parsimony (*and other methods), Version 4. Sunderland, MA: Sinauer Associates; 2002.

87. Huson DH, Bryant D: Application of phylogenetic networks in evolutionary studies. Mol Biol Evol 2006, 23:254-267.

88. Excoffier $L$, Lischer HEL: Arlequin suite ver 3.5: a new series of programs to perform population genetics analyses under Linux and Windows. Mol Eco Res 2010, 10:564-567.

89. Nei M: Molecular Evolutionary Genetics. New York: Columbia University Press; 1987.

90. Pritchard JK, Stephens M, Donnelly P: Inference of population structure using multilocus genotype data. Genetics 2000, 155:945-959.

91. Hubisz M, Falush D, Stephens M, Pritchard JK: Inferring weak population structure with the assistance of sample group information. Molec Ecol Res 2009, 9:1322-1332 
92. Ehrich D: AFLPdat: a collection of $R$ functions for convenient handling of AFLP data. Mol Ecol Notes 2006, 6:603-604.

93. Rosenberg NA, Pritchard JK, Weber JL, Cann HM, Kidd KK, Zhivotovsky LA, Feldman MW: Genetic structure of human populations. Science 2002, 298:2381-2385.

94. Evanno G, Regnaut S, Goudet J: Detecting the number of clusters of individuals using the software structure: a simulation study. Mol Ecol 2005, 14:2611-2620

95. Earl DA, vonHoldt BM: Structure harvester: a website and program for visualizing structure output and implementing the Evanno method. Cons Genet Res 2012, 4:359-361.

96. Jakobsson M, Rosenberg NA: CLUMPP: a cluster matching and permutation program for dealing with label switching and multimodality in analysis of population structure. Bioinformatics 2007, 23:1801-1806.

97. Rosenberg NA: Documentation for Distruct Software: Version 1.1. Michigan: University of Michigan; 2007. https://web.stanford.edu/group/rosenberglab/ distruct.html.

98. Mable BK, Beland J, Di Berardo C: Inheritance and dominance of self-incompatibility alleles in polyploid Arabidopsis lyrata. Heredity 2004, 93:476-486.

99. Säll T, Lind-Halldén C, Jakobsson M, Halldén C: Mode of reproduction in Arabidopsis suecica. Hereditas 2004, 141:313-317.

doi:10.1186/s12862-014-0224-x

Cite this article as: Hohmann et al:: Taming the wild: resolving the gene pools of non-model Arabidopsis lineages. BMC Evolutionary Biology 2014 14:224

\section{Submit your next manuscript to BioMed Central and take full advantage of:}

- Convenient online submission

- Thorough peer review

- No space constraints or color figure charges

- Immediate publication on acceptance

- Inclusion in PubMed, CAS, Scopus and Google Scholar

- Research which is freely available for redistribution 